\title{
Om krigsfangelejrenes oprindelse
}

\author{
Af Bent Rasmussen
}

For fyrretyve år siden gik flag til tops over hele Nordslesvig. De tunge år var forbi.

Glæden var ikke mindst hos de hjemvendte krigsfanger og deres pårørende. Sønderjyske krigsfanger var jo ved særlig foranstaltning blevet sendt hjem over Danmark på et tidligere tidspunkt end andre fanger. Men desuden havde der også i de „allierede“ lande varet oprettet særlige lejre for dansksindede sønderjyske krigsfanger. Nærwærende artikel skal beskæftige sig med spørgsmålet om, hvorf ra initiativet til oprettelsen af disse særlejre stammede.

Slet ikke så få tyske soldater af dansk nationalitet var under krigen 1914-18 blevet taget til fange og anbragt $i$ krigsfangelejrene i Frankrig, England og Rusland. Dette var ikke altid noget behageligt ophold for dem. Man lod fangerne i lejrene have et vist selvstyre, og dette medf $\varnothing r$ te, at de danske, selv om de var undsluppet krigens rædsler, alligevel fortsat skulle være under de tyske officerer.

Ydermere var der på denne måde ikke megen mening $\mathrm{i}$, at disse fanger skulle have samme behandling som de øvrige tyske soldater; de havde jo kun nødtvunget deltaget i krigshandlingerne og kunne ikke med nogensomhelst ret regnes for de allieredes personlige fjender. Enhver tysk soldat — „boche“ — var i disse år den almindelige franskmand forhadt; sфnderjyderne kunne godt fortjene at danne en undtagelse herfra.

Af disse grunde blev der oprettet særlige lejre for sønderjyderne - og forresten på tilsvarende måde også for elsassere og polakker („friendly alien enemies“) - i England, Frankrig og Rusland, et foretagende, som var i høj grad på sin plads, og som 
også blev overordentlig påskønnet af disse fanger. Mange af dem holder sammen endnu i deres foreninger, "Aurillac-Foreningen", „Feltham-Foreningen“ og „Foreningen af forhenværende Krigsfanger i Rusland“, hvor de mødes en gang årlig og opfrisker gamle minder og vedligeholder kammeratskabet, et kammeratskab, som synes at skulle holde indtil døden.

Eren for, at der oprettedes en sådan speciallejr i Frankrig, tilkommer afdøde professor ved Sorbonne i Paris Paul Verrier, en mand, hvis navn er kendt $i$ vide kredse herhjemme på grund af hans kærlighed til Danmark og Sønderjylland og på grund af hans store kendskab til danske og i det hele taget nordiske forhold, sådan som det har givet sig udtryk i adskillige foredrag og skrifter — også på hans gentagne rejser hertil. En udførlig redegørelse for professor Verriers arbejde for at få oprettet den sønderjyske særlejr i Aurillac vil man finde i den af hans efterlevende hustru Ida Verrier udsendte bog PAUL VERRIER OG NORDEN, 1946, side $95 \mathrm{ff}^{1}$.

Da gymnastikdirektør $N$. H. Rasmussen, København, den 10. december 1914 henvendte sig til professor Verrier om at fá noget gjort for de sønderjyske krigsfanger i Frankrig, viste det sig, at Verrier forlængst havde taget arbejdet op for denne sag. Allerede den 11. august 1914 havde han været $\mathrm{i}$ ministerierne for at udvirke begunstigelser for sønderjyderne og elsasserne.

Sagen havde vanskeligheder. Fjenden stod i landet og nærmede sig Paris. I efteråret flyttede regeringen til Bordeaux; der kom nye mænd og nye kontorer, og man måtte i nogen måde begynde forfra igen; men Verrier blev udholdende ved, og den 4. maj 1915 ankom de første 27 sønderjyder til Aurillac og blev installeret i „Ecole Albert“, en katolsk skole, som var blevet beslaglagt til dette formål.

Efterhånden kom der flere, således at der i 1919 var seks-syv hundrede. Disse var dog ikke alle samlet i „depotet“; på forslag af N. H. Rasmussen blev de i skiftende småhold sendt ud hos egnens bønder til hjælp ved høslæt og andet landarbejde'. Dette var uden tvivl en sund afveksling fra kasernelivet, selv om det måske nok ikke uden videre var behageligt !

Et af punkterne i det forslag, som professor Verrier i marts 
N. H. Rasmussen. Fru Marie Rasmussen fot.

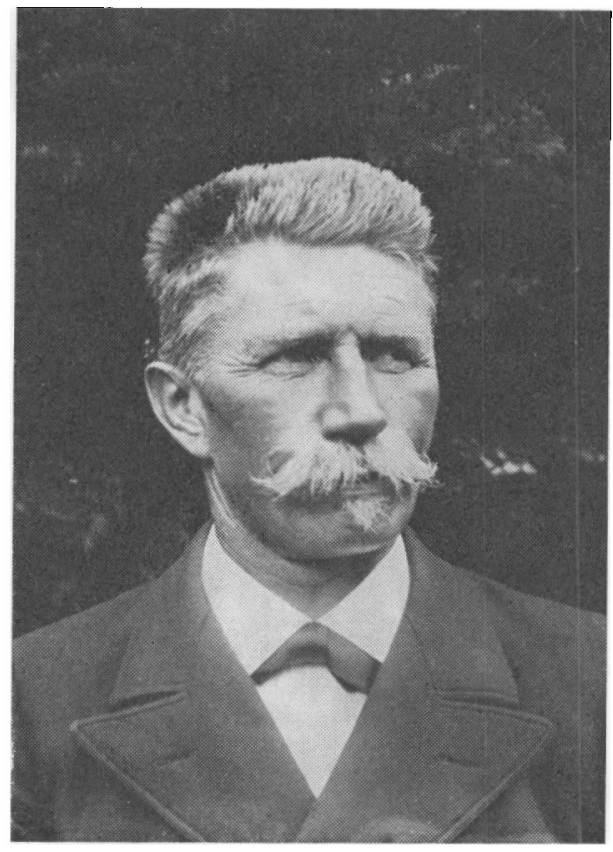

1915 havde tilstillet myndighederne angående særlejren for de sønderjyske fanger, var, at der skulle gives adgang for en dansk præst til at opholde sig $\mathrm{i}$ lejren og holde gudstjenester og foredrag for fangerne. N. H. Rasmussen, som havde syslet med den samme tanke, satte sig derfor i forbindelse med pastor $N$. A. Jensen, tidligere Jernved, med det resultat, at pastor Jensen den 5. oktober 1915 afrejste til Aurillac4. Hans ophold i lejren fik imidlertid ikke så stor betydning, som man havde ventet sig; fangernes deltagelse i landarbejdet gjorde, at der kun var små og skiftende hold hjemme i lejren, så der ikke kunne фves en gerning, som der var nogen rigtig samling over. Pastor Jensens ophold i Aurillac kom derfor kun til at strække sig over en enkelt vinter.

Det f $\varnothing$ rste, som skete i England for at komme de s $\varnothing$ nderjyske krigsfanger til hjælp, var, at den danske sømandspræst i Newcastle-on-Tyne, $A$. Troensegaard-Hansen, rejste rundt til de for- 
skellige fangelejre for at få s $\varnothing$ nderjydernes navne og adresser konstateret, tale med dem og være dem til opmuntring ved sine besøg, holde dansk andagt for dem og være dem til hjælp på forskellig måde'.

Dette var kommet i stand derved, at $\mathbf{N}$. H. Rasmussen, som var medlem af bestyrelsen for „Dansk $\$ \varnothing$ mandsmission i fremmede Havne“, henvendte sig til Troensegaard-Hansen og foreslog ham at tage dette arbejde op'.

Troensegaard-Hansen udf $\varnothing$ rte her et meget betydeligt arbejdes. Det drejer sig om over $50.000 \mathrm{~km}$ jernbanerejser samt - hvad der var meget væsentligt - et omfangsrigt arbejde på krigsministeriets kontorer. Troensegaard-Hansen havde adgang til at gennemse listerne over tilfangetagne på Krigsfangevæsenets Oplysningskontor; ved at gennempl $\varnothing$ je disse lister fandt han s $\varnothing$ nderjydernes navne og adresser frem.

Det måtte falde naturligt også for Englands vedkommende at $\phi n s k e$ sig s $\varnothing$ nderjyderne ud af de tyske fangelejre. Det ser ud til, at N. H. Rasmussen har beskæftiget sig med tanker om dette så tidligt som i begyndelsen af 1915 . Det skal dog siges, at de foranstaltninger, som i f $\emptyset$ rste omgang foresvævede ham, var ikke så lidt forskellige fra dem, som virkelig lod sig bringe til udførelse. $N$. H. Rasmussen var idealist; han fattede de mest højtflyvende planer og gik uden betænkning løs på hvemsomhelst for at få hjælp til deres virkeliggørelse. Måske var netop dette forhold medvirkende til, at han udrettede så meget som han gjorde.

Det vil vistnok være rigtigt her at gengive hele det brev, han den 7. februar 1915 sendte til Sir William Lawrence i det engelske krigsfangevæsens oplysningskontor („Prisoner of War Information Bureau“). Det lyder i dansk oversættelse som følger.

„Sir William Lawrence!

Min kære Herre!

For Deres venlige brev af 4. februar takker jeg Dem på det bedste. Deres venlighed synes at give mig tilladelse til at henvende mig til Dem igen, særlig fordi De skriver: „Krigsministeriet overvejer til stadighed, hvordan man bedst kan fremme arbejdet med censurering og afsendelse af fangernes korrespondance".

Efter at jeg havde skrevet mit forrige brev modtog jeg flere 
N, H. Rasmussen og pustor Troensegaard-Hansen planlagger krigstangearbejdet. Fru Marie Rasmussen fot.

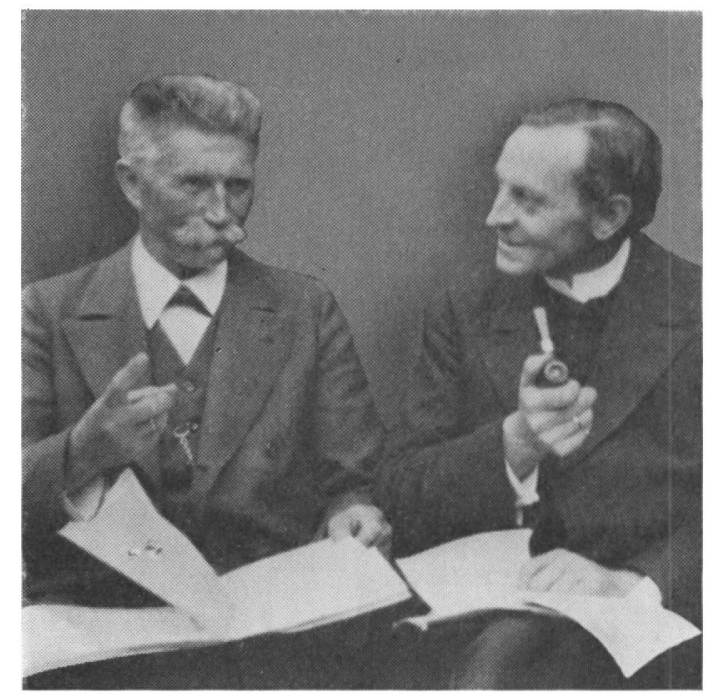

breve fra fanger i England, skrevet på tysk, fordi - skrev fangerne — det ikke mere var tilladt at skrive på dansk. Det er dog kun fra eet sted (Templemore), at der er kommet sådanne tyske breve; fra andre steder er der senere kommet breve, der var skrevet på dansk. Men nu ligger det nær at spфrge: Når fangerne kan skrive dansk nogle af stederne, kan de så ikke gøre det andre steder? Måske har lejren i Templemore ikke haft nogen, som kunde gennemse de udgående danske breve; men kunde i så fald ikke de danske breve gå til et centralkontor i London og få deres gennemsyn dér og kun dér? I Frankrig var det før jul sådan, at flere af brevene fra fangerne der var skrevet på tysk eller engelsk, fordi det ikke alle vegne var fangerne tilladt at skrive dansk. Den alvorlige f $\phi$ lge af dette påpegede jeg for hr. Paul Verrier, professor ved Sorbonnen og vel kendt med Danmark og også med sønderjyderne. Resultatet af min henvendelse til hr. Verrier var et telegram fra ham 29/12: „Send navne adresser. Verrier“. Og derefter 7/1: „Dansk autoriseret. Adressér til mig breve aviser bøger. Verrier". I et telegram spurgte jeg ham, om også fangerne - ikke alene de, der skrev til dem herfra - måtte skrive dansk, og endvidere spurgte jeg ham, om fangerne også kunde sende deres breve til ham. Som 
svar på dette telegram fik jeg følgende telegram fra hr. Verrier, 22/1: „Dansk autoriseret fangerne adresserer breve som hidtil men deres korrespondenter til krigsministeriet eller bedre til mig. Verrier" . Efter dette - som senere er blevet meddelt officielt i den franske presse - har vi i Frankrig fuldstændig fri bane for dansk korrespondance, fangerne såvel som vi, — hvad sproget angår. Sir William, kunde vi ikke, om på nogen måde muligt, opnå den samme frihed i England som i Frankrig? Vi har ikke noget udestående med Frankrig og har aldrig haft det. Men det kan ikke nægtes, at hvad afstamning angår, så er vi danske og vore sønderjydske venner i meget nærmere familie med englænderne end med franskmændene. Jeg kunde tænke mig, at De vilde være så god at sige (kun med undtagelse af politiske aviser ${ }^{\star}$ ) — : „hvad der kan lade sig g $\varnothing r e$ i Frankrig, kan også lade sig gøre i England“. En begunstigelse $m$. h. t. brevenes sprog kan efter min mening ikke afstedkomme nogen ubehageligheder eller irritation for de tyske fanger.

Når De skriver, at „hvis de andre fanger opdagede, at der blev vist sønderjyderne særlige lempelser, vilde disse mænds stilling blive gjort meget ubehagelig““, så tør jeg ikke modsige Dem; for De ser, hvad sandt der kan ligge deri. Sandt, men s $\phi$ rgeligt! For to små sider, to gange om ugen, er kun lidet, særlig da når brevskriveren ikke er skrivevant og derfor holder stor af stand mellem linierne og tilmed bruger meget store bogstaver. Desuden vil jeg tro, at sønderjyderne, hvis der blev givet dem en særlig tilladelse, vilde passe på med den, sådan at tyskerne ikke fik noget nys om den; for s $\varnothing$ nderjyderne er gennem halvtreds år vænnet til at man $\varnothing v r e r e$ mellem prøjsiske skær, og til de tyske soldater vil de ikke fortælle mere end de vil. Man kunde måske g $\varnothing$ re et foreløbigt fors $\emptyset \mathrm{g}-\mathrm{i}$ så fald med „slesvigere“ taget som et geografisk begreb?

- _ - Men en anden sag, Sir William, hvis De vil have tålmodighed til at læse mere endnu fra min hånd, - en anden sag og dog den samme!

En sønderjydsk fange i Frankrig skrev til mig (3/1) : „... Ja, det vilde rigtignok være noget for os, der er bønder til hobe, at komme ud og hjælpe de franske kollegaer. Dersom vi kunde det,

- Kan fangerne modtage andre blade, landbrugsfaglige, religiøse osv.? 
det er det højeste ønske, vi har. Og hvorfor skulde det ikke kunne lade sig g $\varnothing \mathrm{re}$ ? Vi er ikke draget til Frankrig med fjendtlige f $\varnothing l e l-$ ser; det var en hård, brutal pligt, som tvang os dertil. Havde vi sфnderjyder magt, som vi har agt, så havde vi overhovedet ikke hørt til Tyskland, men til Danmark, og så kunde vi være blevet fredeligt hjemme; men dette, dette er velsignelsen ved at stå under en stor nation .... Vi danske betragter slet ikke franskmændene som fjender, og aldrig .....".

Dette brev tog jeg mig den frihed at vise den franske minister $i$ København. Han skrev bagefter til mig: „.... Ved f $\varnothing$ rste lejlighed vil jeg i Paris anbefale de pågældende som landarbejdere“.

Kære Sir William, kunde det slet ikke tænkes, at vore sønderjydske fanger fra Nordslesvig blev sendt ud til de skotske eller engelske bønder for at hjælpe dem med deres jord, hjælpe dem nu i det kommende forår og sommer på et tidspunkt, hvor mange af bøndernes hjælpende hænder er ved hæren. Efter min mening kunde De udmærket sende de nordslesvigske fanger ud til skotske bønder — formelt under sognefogedernes opsyn — ; det vilde blive både til glæde og gavn for begge parter. De sønderjydske fanger kan udmærket godt gå løse. De er ,adelsmænd i bondekofte“ og vil gøre deres pligt på de skotske marker og gøre den med glade, og langt, langt foretrække arbejdslivet dér for livet i lejren. Jeg regner de nordslesvigske bønder for mænd af en sådan kvalitet, at vi ikke har dem bedre her $i$ landet eller $i$ noget land overhovedet. Første klasses helt igennem! Og når vi har et håb, et stille dybt håb, om at få vore landsmænd tilbage efter krigen, så grunder jeg for min part i nogen måde mit håb på, at sønderjyderne er sådan værdifulde mennesker.

Sir William! Jeg beder Dem, tænk over det: Sønderjyderne til Skotland, til bønderne der. . . . . Med hensyn til de tyske fanger og min tanke - for tanken stammer fra mig —, skulde jeg mene, at tyskerne ikke skulde beh $\varnothing v e$ at få noget at vide om dens udf $\emptyset$ relse f $\varnothing \mathbf{r}$ efter krigen. For nu i $\varnothing$ jeblikket skulde det bare være en ordre til hr. N.N. og hr. M.M.: „March!“ Og først bagefter vilde sønderjyderne opdage, at de var kommet til Skotland til en gård og til gårdejeren og hans familie! For et syns skyld kunde der måske blive udtaget et par tyskere også? 
Ved en sådan ordning vilde landmanden få hjælp — måske ikke nødvendig hjælp, men så dog nyttig hjælp —, den britiske stat vilde spare udgifter til fangens forplejning, og fangen selv vilde få beskæftigelse og - stor frihed til at skrive breve! Og landmanden og krigsfangen vilde - det er jeg vis på — begge to få glæde af hinanden.

Sir William! Jeg skylder også at takke Dem for Deres oplysninger om lejrene og adresserne. Og nu lægger jeg hele sagen i Deres hånd - og i Deres hjerte! Bring ud af det, hvad De kan. Om Deres gode vilje nærer jeg ingen tvivl.

Med alle gode $\emptyset$ nsker for Dem og for England -

Deres

N. H. Rasmussen ${ }^{9} "$.

Brevet er gengivet i sin helhed, fordi det er så typisk. Her er ingen officiel stil over affattelsen; N. H. Rasmussen skriver til den engelske embedsmand som om han sad hjemme i sin egen stue og snakkede med ham, og som om han var en gammel bekendt; uden at gøre noget fors $\varnothing \mathrm{g}$ på at afpasse sine planer efter det opnåelige, fremsætter han ganske ligeud - man kunne næsten sige „trohjertet" - sine tanker om den løsning, som synes ham selv den ideelle.

Den endelige plan kom til at gå ud på, at man ville søge at få oprettet en særlig lejr for de krigsfanger, som var fra S $\phi$ nderjylland og var dansksindede. Der skete angående denne sag forskellige henvendelser til det engelske krigsministerium i løbet af krigens første å $\mathbf{r}^{10}$, væsentligst ved Troensegaard-Hansen ${ }^{11}$. Denne var $\mathrm{i}$ det hele taget mellemand for al korrespondancen med "War Office“ (krigsministeriet) ${ }^{12}$. Oberst Larking, som var ansat i dette ministerium, udtalte i sin tid til Troensegaard-Hansen: „Jeg har i dag forsфgt at gå Deres breve til Krigsministeriet igennem; men det var stabler og atter stabler, så jeg måtte opgive det. Nu bliver de imidlertid bundtet sammen og henlagt i Krigsministeriets arkiv, så Deres søn engang kan komme og se med stolthed, hvad hans egen far gjorde under den store $\mathrm{krig}^{\mathrm{is}}$.

Det har været tidligt i 1915, at de f $\varnothing$ rste overvejelser om oprettelse af en særlejr for sønderjyderne har fundet sted $^{14}$. Det var 

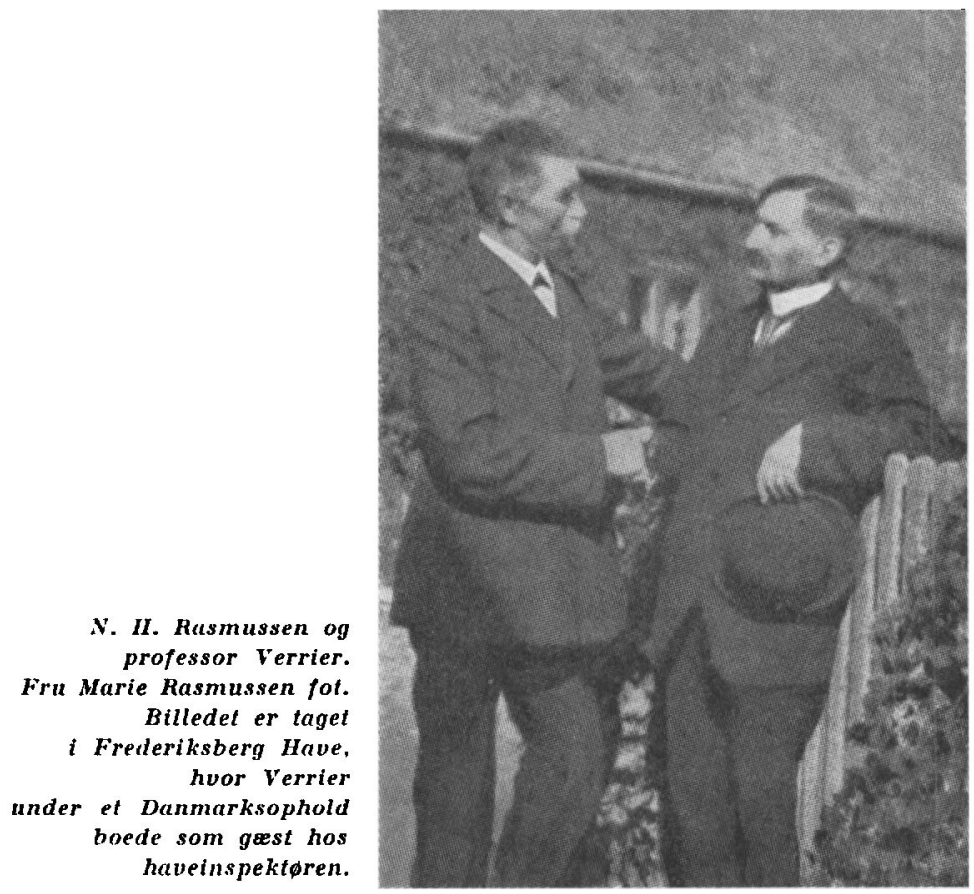

imidlertid f $\varnothing$ rst da professor Verrier var blevet kaldt til hjælp, at sagen kom i skred ${ }^{15}$.

Den 29. marts 1915 skrev N. H. Rasmussen i et brev til Verrier: „.... Gid De kunde få en Londontur og tale med autoriteterne der. Les prisonniers i England har det åbenbart alle godt. Men alligevel! vi vilde jo gerne at vore kære venner S. J. skulde have lidt rigeligt skrivefrihed og også i nogen grad skilles ud fra tyskerne. Men i England har vi ingen Verrier. Jeg har en anelse om, at engl. er en smule mindre vel tilfredse med visse træk fra vor regerings side ...."

Den 27. april 1915 skrev N. H. Rasmussen i et brev til Verrier: „... I I England føles savnet af en fælleslejr. Vi har en dansk s $\varnothing$ mandspræst i Newcastle-on-Tyne. Med varme tager han sig af s $\phi$ nderjyder, rejser rundt til dem og har fri adgang overalt. Han stræber, hvad han kan, efter at få dem samlet sammen, og omsider vil vel dette lykkes; - - men jo f $\phi r$, des bedre. 
Nu er jeg ved Deres gode brev og meddelelse kommen i tanker om, at Frankrig måske kan blive os til hjælp her overfor England.

Kan $\mathrm{f} \phi$ lgende lade sig g $\phi r e ?$

......

(N. H. R. foreslår, at man lader Troensegaard-Hansen foretage en rejse til fangelejren i Aurillac med det dobbelte formål dels at hes $\emptyset$ ge de s $\varnothing$ nderjyske krigsfanger, som på dette tidspunkt var uden dansk præstelig betjening, og dels at skaffe sig grundlag for en henvendelse til de engelske myndigheder om at få oprettet en tilsvarende lejr i England. Han ville med størst vægt kunne stille forslag om en ordning, som han havde gjort sig bekendt med ved selvsyn, og han ville kunne medbringe st $\phi t t e n d e$ udtalelser fra lejrkommandanten eller fra Verrier).

".... Så er der en sag til: ....". (Derefter til sidst i brevet): „Sig mig engang, hvis De muligvis kunde yde en håndsrækning til en Englandsordning (fælles-lejr), kunde De så eventuelt gøre en tur til London for os? . . . " ${ }^{17}$.

Følgen heraf blev, at pastor Troensegaard-Hansen ved pinsetid 1915 foretog den nævnte rejse til Aurillac, hvor han blev de sønderjyske fanger til megen glæde ved sit bes $\phi \mathrm{g}^{18}$.

På nedrejsen aftalte han i Paris med Verrier, at de efter Tr.-H.s tilbagekomst til England skulle mødes i London og sammen gå op i War Office ${ }^{19}$.

Dette skete den 8 . juni $1915 \mathrm{kl}$. 31/2 eftm., efter at Verrier i lobet af den foregående uge havde henvendt sig i ministerierne ad diplomatisk vej som befuldmægtiget af den franske regering.

De to herrer blev på krigsfangevæsenets kontor modtaget af oberst Larking, som forestillede dem for chefen, generall $\varnothing$ jtnant Belfield. „Det er os en forn Verrier, „og vi har været Deres regering meget taknemlig for det, den har gjort for de slesvigske fanger, ligesom enkedronningen har udtalt sig i de varmeste ord om det arbejde, som" (henvendt til Tr.-H.) „De, hr. pastor Troensegaard-Hansen, har udf $\varnothing \mathrm{rt}$ for vore slesvigske fanger, - og vi tænker på at samle disse fanger på samme måde; men vi må først unders $\varnothing g e$, hvor mange slesvigske fanger, der findes i Storbritannien, og vi må anmode Dem, pastor, 


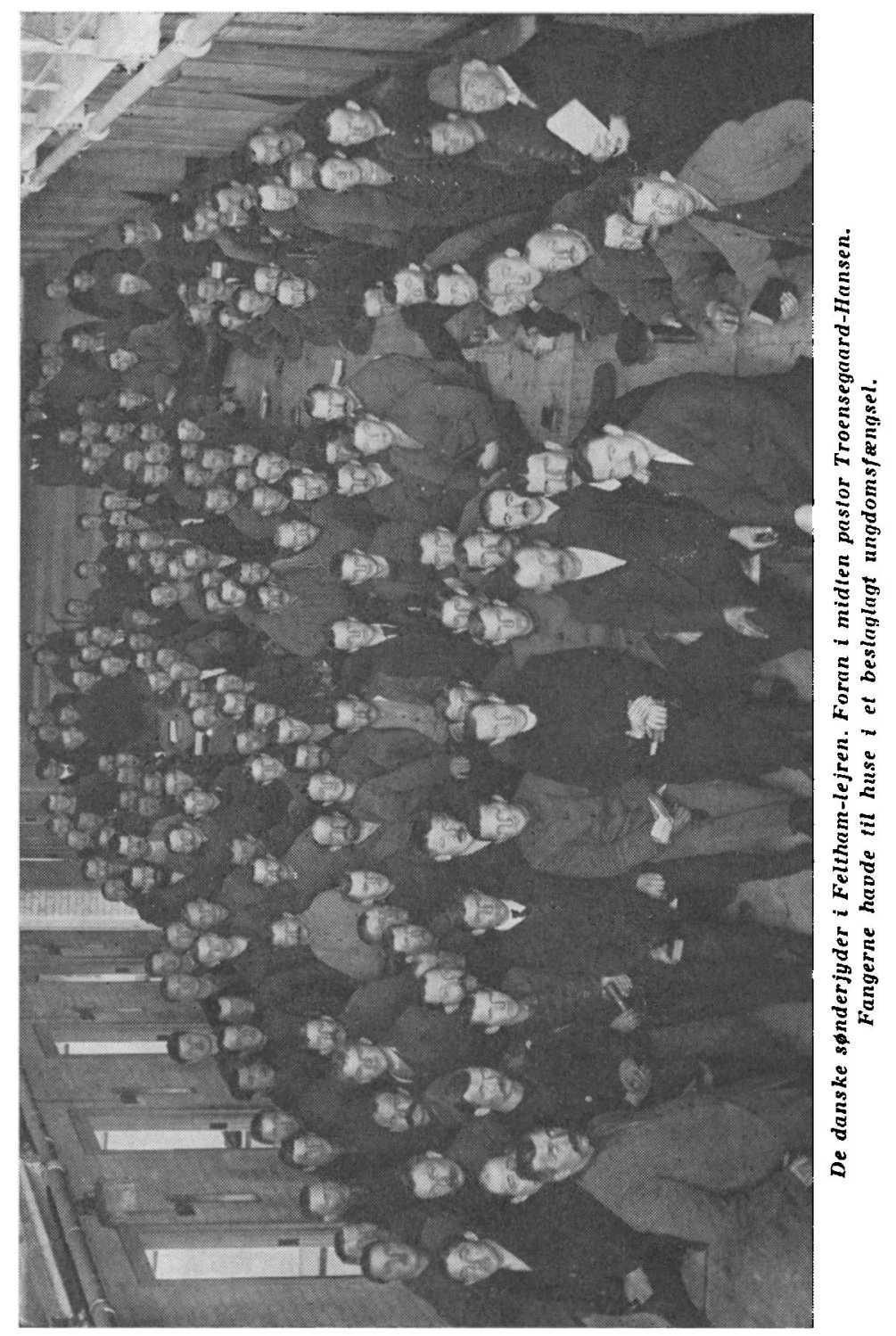


om at rejse rundt til de forskellige lejre og sortere sønderjyderne (,sift the slesvigers“). Vi vil betale Deres udlæg efter regning. I løbet af nogle dage vil der blive udfærdiget en liste over de lejre, vi $\emptyset$ nsker, De skal bes $\varnothing$ ge. Når den foreligger, kan De henvende Dem til oberst Larking, som vil give Dem de forn $\varnothing$ dne papirer" ${ }^{\text {“20. }}$.

Endelig, sidst i juli måned, kom den skriftlige autorisation til pastor Troensegaard-Hansen ${ }^{21}$. Han rejste nu i rask tempo rundt til de forskellige krigsfangelejre og udtog de dansksindede sønderjyder, som skulle på listen for overflytning til dansk særlejr ${ }^{2}$.

Listen voksede hurtigt. Alligevel trak sagen i langdrag. Troensegaard-Hansen fortsatte med at bombardere krigsministeriet med henvendelser. Han fortæller om en af disse, at man svarede ham med at anf $\phi r e$ en mængde betænkeligheder; „vi tør ikke for tyskerne" etc. Troensegaard-Hansen lod sig imidlertid ikke afvise, men forlangte at få foretræde for general Belfield selv (chef for krigsfangeadministrationen). Det fik han. $\mathrm{Og}$ så gav Tr.-H. sig til at fremstille sagen; ,jeg havde jo det hele færdigt, klappet og klart; jeg talte uden kommaer og semikolon'er, omtrent som en grammofon, der er trukket op. Og da jeg så satte punktum og trak vejret, så sagde general Belfield: ,Godt, pastor; nu er jeg gjort bekendt med sagen, og jeg kan sige Dem, at Krigsministeriet vil tage sig af den på allerbedste mảde. Nu kan De tage hjem og udfærdige en liste over Deres kære slesvigere og sende den til oberst Larking, ....."

Kort efter kom de f $\phi$ rste fanger.

De blev installeret i „Feltham Lejren“, en beslaglagt opdragelsesanstalt lidt uden for London. De f $\phi$ rste fire s $\phi$ nderjyder kom dertil den 6. april 1916; efterhånden rummede lejren et par hundrede sønderjyder" ${ }^{24}$. Det var disse til megen glæde at komme hertil. En af dem skrev i et brev: „Gode ven Rasmussen. - Jeg vil i dag skrive et Par Ord til Dem og takke Dem mange Gange for disse smukke Bøger, som jeg har modtaget fra Dem af, og mange Tak for Hans Kirk og Hans Fogh. Ja kære Rasmussen, nu er vi endelig kommen til den nye Camp her i England, og jeg haaber, at her bliver vi alle samlet paa eet Sted .... Det er dejligt her $i$ den nye Camp, her kan man jo dog gaa rolig for Tyskerne, og det er jo meget værd, for de kunde jo ikke godt lide os, der hvor vi kom 


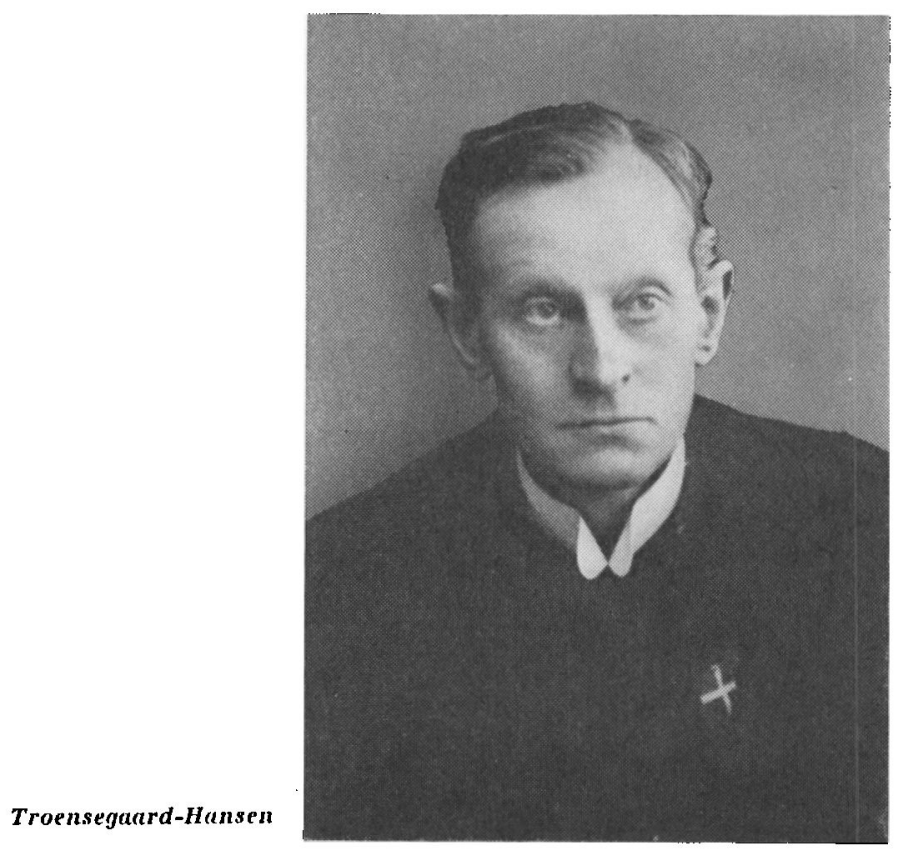

fra, da vi talte vort danske Sprog, og prøvede ogsaa paa at ville forbyde os dette, men der blev jo holdt stærkt paa at det ikke blev til noget. Nu mange Hilsener og mange Tak. ...., No. 122, Sect. A., Prisoner of War Camp, Feltham, England" ${ }^{\text {“2s. }}$.

Troensegaard-Hansen skriver om lejren $i$ et fællesbrev til danske venner af krigsfangesagen :

„Endelig er det lykkedes — dette, som vi har tænkt på, talt om, skrevet om og bedt om, - at vore kære S $\varnothing$ nderjyder ere blevne samlede i en Fælleslejr, ganske vist ikke helt alene, men dog samlede, fri for de truende Blikke, fri for prøjsisk Tvang. De ere atter et frit Folk - trods Fangenskabet - saa de aabent kan tale sammen om de Ting, der sysselsætter deres Tanker tidlig og sent: deres kære Slesvig i Nutid og Frentid. Øjnene kan lyse og straale, naar de tænker paa eller taler om deres lønlige Haab: frit og uden Tvang at kunne bruge det kære danske Sprog i Kirke og Skole, 
Forsamlinger og Møder, at de igen kan faa, hvad de med lovlig Ret kan kræve ....

Kommandanten og hans Officerer er de elskværdigste Mennesker, De kan tænke Dem, Mennesker med Dannelse og Takt og med Forstaaelse for vore „fraskilte Brødre“....

Hver af Krigsfangerne har sit lille Værelse, hvor Væggene ere dekorerede med Danebrogsflag eller Prospekter fra Danmark, i Centrum hænger „det allerbedste“, Billederne af de kære derhjemme. Et Steds er det en Hustru, der sidder med „Krigsbarnet“ paa Armen, den mindste eller eneste, som er f $\varnothing \mathrm{dt}$ under Krigen. Faderen har aldrig set sit „Krigsbarn“. Et andet Sted er det „Huset paa Landet" med hele Familien udenfor og Billedet af en af de faldne .... Saa gaar vi rundt i Klynger og passiarer og ser paa „Herlighederne“, f $\varnothing$ rst til Værkstedet, hvor H $\phi$ vlebænk, Sav og Huggejærn og alle dertil horende Instrumenter bliver flittigt brugt baade af de militære og civile Krigsfanger ....

Og saa gaar vi til Skolen, hvor vore to Lærere, ......, giver deres stadige Undervisning i Dansk Sprog, Historie, Litteratur samt Engelsk og andre Fag. Derfra gaar Turen til den lille Have, hvor Kartofler, Kaal, Guler $\varnothing$ dder og andre Gr $\phi$ ntsager vidner om Landmandens Kærlighed til Naturen og dens Gaver. Indenfor Haven findes „Husdyrene“, d. v. s. Kaninerne, hele store Familier. En Kaninmoder ligger og gumler nok saa fornøjet med et Anstrøg af Stolthed over sin store Flok paa 8 eller 9 B $\emptyset r n$ ! De skulde se mine Venners Glæde over at vise denne Verden frem for mig. Det mindede jo om Hjemmet!

Og saa en stor Sportsplads, hvor de kan drive deres Sport, Gymnastik, Fodbold og anden legemlig Idræt. For Renligheden har vore hygiejniske, renlige Englændere s $\varnothing$ rget paa bedste Maade. Der er mange Badekar og Brus med herligt Styrtebad samt det saa uundværlige W. C.!

Efter at have set paa alle disse mange Ting og spist til Middag $i$ Officersmessen, gik vi over til Kirken, der er en lys og rummelig Bygning, ..... “as.

I et $\mathbf{f} \varnothing$ lgende brev skriver Troensegaard-Hansen:

„Hvad [Gudstjenesten] er for mig, kan ikke beskrives med Ord. Hvad den er for vore Sønderjyder kan man bedst dømme udfra 
den dybe, alvorlige Stilhed, der hviler over den danske Forsamling, der lyttende griber ethvert af Guds Ords herlige Forjættelser ! . . . . Og Salmesangen! Ja, denne henrykker mig tidt: I skulde høre disse Jyder synge vore gamle Kærnesalmer! . . . “" .

Om arbejdet for sønderjyske krigsfanger i Rusland foreligger der en beretning fra N. H. Rasmussens egen hånd, skrevet i 1920 . Det er et manuskript beregnet på trykning i et skrift, som formodentlig var påtænkt udgivet af den daværende forening af forhenværende krigsfanger i Rusland (i lighed med „Aurillac Tidende“ og „Feltham Mindebogen“). Dette skrift nåede aldrig at udkomme. Jeg vil gerne have lov at hidsætte denne beretning nogenlunde i sin helhed, selv om den er noget lang, for det første fordi den er affattet ganske kort tid efter de deri ontalte begivenheder $\longrightarrow$ og affattet af den mand selv, som havde mest med sagen at gøre; for det andet på grund af selve beretningens karakter. I såvel dens indhold som dens form træder dens forfatter lyslevende frem for os. Dette gælder ikke alene dens kantede og malmfulde danske sprog, men det gælder navnlig fortællingens tone, hvor det er hjertelaget, der hele tiden træder frem og præger fremstillingen. Vi ser lige ind $i$,krigsfangesagen"s værksted.

N. H. Rasmussens beretning lyder:

\section{„Sфonderjyderne i Rusland.}

Den Opfordring er bleven rettet til mig, at skrive lidt til nærværende Skrift. Paa Spørgsmaalet: hoad man ønskede, jeg skulde skrive om, fik jeg det Svar, at man gerne vilde vide, hoem der havde arbejdet paa at lette Sønderjyderne deres Tilværelse i russisk Fangenskab.

Til en vis Grad kan jeg vel gøre dette, men heller kun til en vis Grad, og, som man vil forstaa, ikke uden Betænkeligheder. Mange Tanker er gaaet til Krigsfangerne derborte i det fjerne, mange Hænder har her været i Arbejde, ingen kender dem alle. Vi vilde gerne have gjort noget for Jer, gjort meget. Men Forholdene var vanskelige, alt for vanskelige. Især blev det vel kun en Brøkdel af, hvad der sendtes Jer af Pakker og Breve, der kom Jer i hæende.

At dog en Del lykkedes, glæder vi os dybt over, og navnlig glæder 
vi os ogsaa over, at en Stræben herhjemmefra efter at hjælpe S $\phi n-$ derjyderne mødtes med tilsvarende Stræben hos Landsmænd, bosatte eller virkende i Rusland, samt over al den Velvillie, der fra daværende russisk Regeringsside blev vore S $\phi$ nderjyder til Del. Men samtidig tænker vi med Vemod paa dem af vore s $\varnothing$ nderjydske Krigsfanger, som vi ikke kunde naa eller ikke kunde finde i det uhyre Rige, og af hvilke sikkert adskillige har maattet lukke deres $\emptyset$ jne under svære Lidelser og under de ulykkeligste Forhold.

Det laa nær at tænke, at selv om vi kunde finde Sønderjyder i russisk Fangenskab - og efterhånden lykkedes det at faa Adresser paa dog en Del, - saa vilde det maaske være vanskeligt at faa Forbindelse i Stand mellem os og dem og dem og os. Thi Russerne vilde vel ikke kunne censurere Breve, der var skrevne paa dansk; og deraf vilde det kunne være en F $\varnothing$ lge, at den Brevskrivning, der var at $\varnothing$ nske, slet ikke blev til noget.

Den russiske Legationspræst, Hr. I. Stchelkunoff i København, blev her S $\varnothing$ nderjyderne en god Mand. Gaaet i Skole som han har i København, taler han Dansk som en Dansker. Og Sympati havde han paa Forhaand for vore S $\phi$ nderjyder som for Danmark. Han var derfor god at komme til, og han var en god Raadgiver. Efter hans Tilskyndelse indgaves der i de første dage af Marts 1915 ved personlig Henvendelse et Andragende til Ruslands Minister i K $\phi$ benhavn, Baron Ch. de Buxhoeveden af følgende Ordlyd (her i Returoversættelse):

\section{Deres Excellence!}

Endsk $\varnothing n t$ jeg tilstaar, at den Sag, som jeg tager mig den ærb $\phi-$ dige Frihed at henlede Deres Excellences og den høje kejserlige Regerings Opmærksomhed paa, i disse saa alvorlige Tider kan synes at være af kun saare liden Vigtighed, tager jeg dog ikke i Betænkning, stolende paa den Velvillie, som man i Rusland altid har vist imod Danmark og Danskerne, at bede om St $\varnothing$ tte hos Deres Excellence for et Spфrgsmaal, som for mig og Tusinder af Danske er et Spфrgsmaal af den højeste Vigtighed.

Grænselandet Slesvig, som Tyskland har røvet fra os, har længe været oversvømmet af det tyske Element og især efter 1864 af danskfjendtlige Embedsmænd. Imidlertid hersker dansk Sindelag 
og dansk Sprog stadig i den nordlige Del, og ogsaa Mellemslesvig vil hurtig blive dansk igen, dersom det efter en lykkelig Udgang af Krigen blev givet tilbage til Danmark.

Det danske Slesvig har i 50 Aar maattet lide alle Plagerier fra de prøjsiske Undertrykkeres Side, men den mest grusomme Skæbne var endnu forbeholdt dem, da Krigen brød ud og de maatte forsvare Interesser, der ikke var deres, ja som endog stod i Modstrid med deres. Adskillige af disse Danske har været saa lykkelige at falde i russisk Fangenskab og har saaledes Udsigt til engang at kunne vende tilbage til deres $\mathrm{Hjem}$, befriede fra deres Undertrykkeres Aag. Men Fangenskabet kan ikke andet end tynge dem. Adskillige i Danmark har da tænkt paa at mildne dem dette Fangenskab ved at sende disse danske Fanger Breve, Tryksager og Gaver. Vi har set, hvorledes i Frankrig og i England saadanne Sendinger er blevet skattede iblandt Krigsfangerne. Og vi regner ogsaa med det gunstige Indtryk, som det vil gøre, naar Krigsfangerne engang vender hjem og de da vil kunne sige, at de var ikke bleven glemt af deres gamle Landsmænd. Vort Arbejde har altsaa en national Betydning.

I Frankrig og i England har der været temmelig store Hindringer at overvinde, Hindringer der var skabt ved midt i Krigen og mens der var Travlhed med andre Ting, da at skulle sørge for Censur. De militære Autoriteter havde ikke altid Folk til Raadighed, der forstod Dansk. Og disse samme Vanskeligheder vil maaske ogsaa være tilstede for Ruslands Vedkommende. Men for at prøve at bortrydde disse Vanskeligheder tillader jeg mig at fremstille for Deres Excellence, hvorledes Sagen er bleven ordnet i Frankrig.

Før Jul havde jeg overfor Hr. Paul Verrier, Professor ved Sorbonnen i Paris, fremholdt, hvor pinligt det var, at de danske, der gik som Krigsfanger, i visse franske Byer ikke kunde faa Tilladelse til at brevveksle paa Dansk med deres Venner, men at de var nødte til at betjene sig af det tyske Sprog! Takket være Hr. Verriers Mellemkomst overfor Autoriteterne, er det lykkedes at faa Brevveksling i Stand, saaledes at de danske Krigsfanger faar deres Post og afsender deres Breve igennem Hr. Paul Verrier i Paris, der af Krigsministeren har faaet overdraget det Hverv at censurere ..... 
I England har Censurspфrgsmaalet ligeledes voldt Vanskeligheder, men vi haaber ogsaa der at naa til et tilfredsstillende Resultat.

Hvad angaar Rusland, tillader jeg mig at vende mig til Deres Excellence med B $\phi n$ om, at De vil interessere Dem for en Ordning svarende til den, vi har opnaaet i Frankrig, til Gunst for de slesvigske Krigsfanger, der er fangne i Rusland. Jeg t $\phi r$ tro, at saafremt den kejserlige Regering er tilbøjelig til at stille sig imødekommende overfor en saadan Ordning, da vil det vist ikke være umuligt i Petrograd at finde en Mand, som man kunde formaa til at paatage sig samme Arbejde som Hr. Verrier i Frankrig. For kun at nævne et Navn, kunde jeg saaledes nævne $D r$. v. Barner ${ }^{*}$, f $\varnothing \mathrm{dt}$ dansk, som sikkert vilde paatage sig dette Arbejde eller kunne pege paa en Mand, som den russiske Regering kunde have Tillid til. Jeg har for $\emptyset$ vrigt allerede gjort Skridt i denne Retning overfor Hr. N. Egoroff * , Embedsmand i Undervisningsministeriet i Petrograd, ved at spørge denne, om han eventuelt vilde vare villig til at paatage sig Militærcensuren over de slesvigske Krigsfanger $i$ Rusland. Dersom Hr. Egoroff er villig hertil, vil Stillingen være saa meget mere gunstig, som den kejserlige Regering da vilde have at gøre med en af sine egne Embedsmænd.

Stolende paa det gamle Venskab, der i saa lange Tider har raadet i Rusland ligeoverfor Danmark, $t \varnothing r$ jeg haabe, at man vil have den Godhed at yde os den værdifulde St $\varnothing$ tte for Ordning af en Sag, der ved Siden af de store Begivenheder synes meget lille, men som for os er af stor Vigtighed, og som ligger os særdeles paa Hjertet ..... (Undertegnet) ${ }^{28}$.

Allerede den 10. April 1915 indløb der Svar paa Henvendelsen til den russiske Minister i K $\phi$ benhavn. Baron Buxhoeveden skrev ganske kort, men saa imødekommende som muligt (Oversættelse):

I Svar paa Deres Brev af 6. Marts har jeg den Ere at underrette Dem om, at den russiske Militærcensur har faaet Ordre til at lade de tyske Krigsfanger af dansk Afstamning i Rusland have Lov til

* Dr. v. Barner havde allerede $i$ et Brev fra Februar 1915 erklaret sig meget rede. N. H. R.

* Ogsaa Hr. Egoroff havde i Februar paa den elskværdigste Maade stillet sig til Raadighed, hvis der fra dansk Side kunde opnaas Tilladelse dertil hos den russiske Regering. .... N. H. R. 


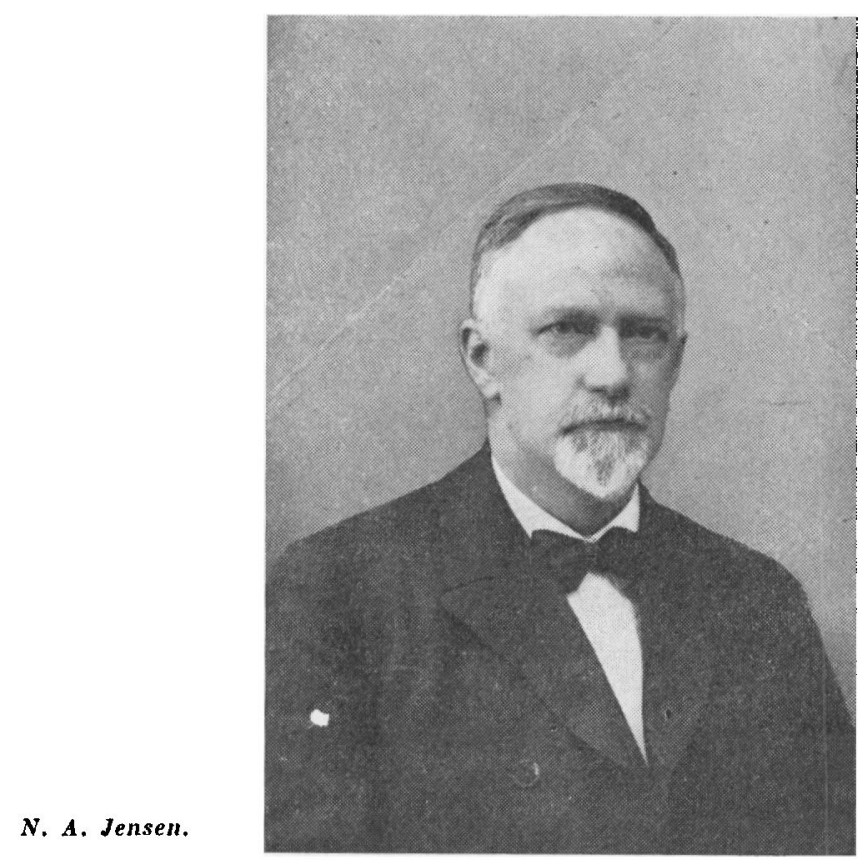

at brevveksle paa Dansk med deres Landsmænd i Danmark ... . (Undertegnet) ${ }^{20}$.

Hvem der saa senere kom til at ud $\phi v e$ Censuren over de danske Breve og Bøger, Dr. Barner, Hr. Egoroff eller helt andre, vides der intet om. Men at vi fik Tilladelse til at f $\phi$ re dansk Brevveksling, skylder vi den russiske Hjemmeregering, den russiske Minister i København, Baron Buxhoeveden og hans Legationspræst, Pastor Stchelkunoff Takken for. Den russiske Legation har overhovedet helt igennem stillet sig saa velvilligt som muligt til de sønderjydske Krigsfangers Sag. Endnu saa sent som 20. August 1917, skrev Legationssekretæren, Hr. Boris Deruginsky, i Anledning af et Andragende, om hvilket jeg ikke mere husker, hvad det gik ud paa:

„I Besiddelse af Deres Brev af 17.8.17 tillader jeg mig at meddele Dem, at Deres Andragende bliver sendt videre til Udenrigsministeriet. Samtidig vilde jeg med Forn $\varnothing$ jelse anbefale denne Sag i Petrograd, hvorhen jeg rejser d. 26. ds. Jeg vil meget gerne st $\phi$ tte 
ogsaa andre af Deres $\emptyset$ nsker, hvis De vil give mig et lille Memorandum om, hvad De vil, jeg skulde frembære i Petrograd. Deres hengivne Boris Deruginsky, Legationssekretær" ${ }^{\text {“æmon. }}$

Tænker vi paa saadanne Russeres Godhed overfor vore S $\varnothing$ nderjyder, da bidrager ogsaa dette sit til at g $\phi$ re det svært for os nu at se paa Ruslands Sammenbrud. Som en liden Trøst er det, at de Danske i Sønderjylland var gode imod de russiske Krigsfanger, der i Krigens Tid blev sendt dem som Arbejdere; ligeledes ogsaa at Borgmester Bruun og Frk. v. Stemann i Ribe, Dr. Fiedler i Assens og flere Danske var gode imod de Russere, der gennem S $\varnothing$ nderjylland kom flygtende ind over vore Grænser. Vi vil alle af Hjertet $\varnothing$ nske det russiske Folk, dette Folk med Barnesindet, en Genoprejsningens Tid, ny og bedre Lykke.

Men tilbage til Fmnet.

Det kan nævnes, at der i Begyndelsen af 1915 var kommen Forbindelse i Stand med en dansk Mand i Rostow ved det Asovske Hav, nu afd $\varnothing$ de Konsul Andr. Nissen. Konsulen var tilfældigvis i København i Marts 1915, og her blev han da anmodet om, naar han kom til Petrograd paa Hjemvejen, da personligt at s $\varnothing$ ge Enkekejserinde Dagmar og bede Hendes Majestæt lægge sin store Indflydelse i Vægtskaalen for de sønderjydske Krigsfanger i Rusland. Hvor meget den høje Dame, Danmarks trofaste Datter, har gjort for S $\emptyset$ nderjyderne i Rusland, og navnlig ogsaa hvor meget hun har gjort for Oprettelsen af Særlejren i Pawlowo Possadskii, den, der senere flyttedes til Jurjeff Polskii, kan ikke oplyses her, men jeg har Grund til at tro, at det er uendelig meget. Og Sønderjyderne vil vide hende deres $\mathrm{Hjertes}$ dybeste Tak herfor.

- Der var altsaa for saa vidt fri Bane $m$. $H$. t. at sende danske Breve til sønderjydske Krigsfanger i Rusland. Men hvorledes? Som kendt, havde det danske „Røde Kors“ paataget sig at være Mellemmand mellem Centralmagterne og disses fangne Soldater i Rusland. Vilde „R $\varnothing$ de Kors“ tage sig af det, der fra Danmark sendtes til S $\varnothing$ nderjyderne i Rusland? En Skrivelse herom blev 25. April 1915 sendt til det danske „R $\varnothing$ de Kors“, der i Svar af 28. April 1915 gjorde opmærksom paa, at dets europæiske Hverv var at tilvejebringe tilfredsstillende Forbindelse „mellem Fangerne og deres Hjemland og omvendt", og at man derfor allerede for nogen Tid si- 
den havde maattet afslaa at bes $\phi$ rge Forsendelser fra Personer, boende i Danmark eller andre neutrale Lande. Dette lød jo ikke opmuntrende. Saa meget glædeligere var Slutningen af „Rode Kors"' Svarskrivelse: "Ikke desto mindre har Afdelingen nu ment at kunne give den ganske enkelte Undtagelse at besørge Breve og Pakker til Krigsfanger i Rusland, som er hjemmeh $\phi r e n d e$ i $S \phi n-$ derjylland".

Brevskrivning m. m. fra Danmark til de krigsfangne Landsmænd i Rusland kom da igang. Men kunde en Dansker skrive alt, hvad han vilde? Neppe. I alt Fald fik jeg 2. Dec. 1915 et Brev fra „Røde Kors“ saalydende: „Da det er en Selvf $\phi$ lge, at der gennem en nevtral Institution som „Røde Kors“ aldrig bliver afsendt Breve af politisk Indhold, skal vi herved tilbagesende Deres vedlagte Brev“. Et af mine Breve til en Krigsfange havde altsaa varet for kriminelt til at kunne bes $\phi$ rges af „R $\varnothing \mathrm{de}$ Kors“. Dertil var intet at sige. Men jeg var jo ikke meget tilsinds at indskrænke mig til at skrive om Vejr og Vind og lignende nevtrale Sager og pønsede derfor paa at komme udenom „Røde Kors“ m. Hs. t. Breve. Der blev da lavet Adressesedler til at klæbes paa Breve, til Brug for Krigsfangegudm $\varnothing d r e n e^{\star}$ og bærende russisk Tryk, der oplyste det russiske Postvæsen om, at den russiske Regering havde tilladt dansk Sprog til og fra de sønderjydske Krigsfanger i Rusland. Og til Krigsfangerne sendtes der herhjemmefra Konvolutter med det samme Tryk paa, til Brug for de Breve, de vilde sende til Danmark. Og fra nu af gik Brevene igennem Postvasenet og udenom „Rфde Kors“. Derimod blev „Rфde Kors“ ved med at sende Pakkerne afsted; og det $t \phi r$ formodes, at flere Pakker paa den Maade er kommen frelst igennem, end Tilfældet ellers vilde have været; ligeledes har „Røde Kors“ hjulpet os ud over de Vanskeligheder, som Udf $\varnothing$ rselsforbud ellers lagde i Vejen for Forsendelse af forskellige Ting. Vi har derfor Aarsag til at være glade for al den Hjælp, der fra „Røde Kors"s Side er ydet ved Expedering derigennem til de s $\varnothing$ nderjydske Krigsfanger. I „R $\phi$ de Kors“s Kontorer sad der iøvrigt i den store Stab af arbejdende Kræfter en Dame,

* Betegnelsen for de danske, som havde påtaget sig at korresponclere hver med en enkelt af de sønderjyske krigsfanger. B. R. 
Frk. Jane Wolff, som der er den allerstørste Grund til særlig at fremdrage fra hendes Skjul. Med den $\varnothing$ mmeste og inderligste Kærlighed gjorde Frk. Wolff alt hvad hun kunde for Sønderjyderne; hendes søgende $\emptyset$ je fandt tit et Navn eller en Adresse paa en i det ukendte; og mange Ting til Gavn kom hun i Tanker om; og aldrig blev hun træt. Endnu den Dag i Dag tænker hun, er jeg vis paa, paa sine gamle „russiske“ Krigsfanger.

I Januar 1916 dukkede der et nyt Navn op, et saare godt Navn. Det var Vicekonsul Fr. Edstr $\phi m$ ved det danske Konsulat i Moskwa, fra hvem der kom Brev, hvori han skrev, at han „efter modtagen Skrivelse fra Krigsfange Clausen, fra Aabenraa, Nygade 4" vilde meddele Navnene paa nogle Sønderjyder, der var komne til Særlejren Pavlovo-Possadskii (nogle faa Mil fra Moskwa). Konsulen anmodede om, at den ny Adresse maatte blive sendt til de Paagxldendes Hjem, og han oplyste, at der trængtes til lidt Penge. Det laa straks klart for Dagen, at Konsul Edstrøm var og vilde blive en ualmindelig og ganske udmærket St $\phi$ tte for S $\phi$ nderjyderne, og dette stadfæstede sig Gang paa Gang frem gennem 'Tiden. I sit næv'nte Brev gjorde Konsul Edstrøm opmærksom paa, at Breve til ham kunde sendes gennem det danske Udenrigsministeriums Kurér til den danske Legation i Petrograd til Videresendelse derfra til Moskwa. Dette var en saare behagelig Oplysning. Det gav Sikkerhed for Breves Fremkomst, og det var Tegn paa, at danske Regeringsrepræsentanter i Rusland ikke var bange for at hjælpe Sønderjyder, der var i Nød. Fremtiden skulde vise, at i den danske Legation i Petrograd havde Sønderjyderne i Rusland deres bedste Venner. Det anf $\phi$ rte glædelige Brev fra Konsul Edstrøm, dateret 30.(17.) Dec. 1915, kom ikke direkte til mig, men blev mig sendt fra den danske Minister i Petrograd, Hr. Kammerherre Harald Scavenius - Danmarks nuværende Udenrigsminister - og ledsagedes af følgende ligesaa glædelige Brev, 18. (5.) Jan. 1916, fra Ministeren selv: „Jeg sender Dem hoslagt en til Dem adresseret Skrivelse fra det danske Konsulat i Moskwa, hvoraf De vil se, at 8 Slesvigere nu er samlede $i$ Nærheden af Moskwa. Hvad angaar deres Behandling, skriver Konsulen i en Beretning til mig: „S $\varnothing$ nderjyderne faar bedre Behandling end andre Krigsfanger; de har mere Frihed, bor sammen og kan tale dansk sammen. Det betrag- 
tes her som en stor Fav $\varnothing$ r, at man fra Sibirien har sendt disse til Pavlovo-Possadskii. Jeg har som en forel $\varnothing$ big Hjælp sendt $100 \mathrm{Rub-}$ ler til Konsulen med Anmodning om at fordele dem mellem Sønderjyderne. Konsulen er endvidere i Færd med at opnaa Tilladelse for dem til at modtage danske Bøger; saasnart Tilladelsen opnaas, vil der saavel herfra som fra Danske i Rusland blive sendt Bøger for paa den Maade efterhaanden at oprette et Slags Bibliotek. Jeg sender Dem indlagt de Uddrag, jeg har af Fangelisterne. Maaske vil det være Dem muligt at meddele mig, hvilke af de her opførte, der er danske. Formaalet maa jo være at faa saa mange som muligt under samme gunstige Forhold“.

„Fra Danske $i$ Rusland" — hed det i foranstaaende Brev. Ja, „Danske i Rusland tog i Aarenes L $\phi$ b store Tag for deres og vore krigsfangne Landsmænd. Dette gælder i fremragende Grad den $\emptyset$ verste og ypperste af alle Danske i Datidens Rusland, H. M. Enkekejserinde Dagmar. Hvor vil det ikke glæde alle Sønderjyder at læse følgende Brev af 29. Jan. 1916 fra Kammerherre Harald Scavenius: „I Fortsættelse af min Skrivelse af 18. Jan. d. A. undlader jeg ikke at meddele Dem, at jeg fra Hendes Majestaet Kejserinde Maria Feodorovna har modtaget 800 Rubler samt 8 Pakker med varme Klæder til de sønderjydske Fanger i Pavlovo Possadskii. Kejserinden anmodede mig samtidig om at ville meddele Kommandanten i Moskwa, at de sønderjydske Fanger kunde korrespondere paa Dansk med deres Paarørende. Dette er nu gjort, og efter Meddelelse fra Konsulatet i Moskwa er de nødvendige Ordrer i saa Henseende udstedt".

D. 5. Febr. 1916 skrev Kammerherre Harald Scavenius:

„Jeg har modtaget Deres Brev, for hvilket jeg takker Dem. Jeg har nu faaet Meddelelse om, at der i Pavlovo Possadskii befinder sig 23 Sønderjyder, nemlig ...... (Navnene). Der findes tillige her i Rusland 26 krigsfangne Sønderjyder, der endnu ikke er kommen til Pavlovo Possadskii, nemlig ...... (Navnene).

...... (en af Fangerne) har tilskrevet Konsulatet i Moskwa, at han meget $\emptyset$ nsker at modtage medicinske videnskabelige Værker, enten anatomiske, fysiologiske, kemiske eller fysikalske. Skulde De kunne sende saadanne Bøger, vil det være mig en Glæde at bes $\emptyset$ rge dem. De bedes sende dem gennem min Familie, Stock- 
holms Plads 1, Kbhvn., i Pakke adresseret direkte til mig; min Familie kan saa lade dem gaa med Udenrigsministeriets Kurér. I Fangelejren i Viatka findes f $\emptyset$ lgende s $\emptyset$ nderjydske Krigsfanger . . .... (Navnene paa 5) samt endnu nogle Stykker, hvis Navne ikke kendes "st.

Mellem mine Papirer finder jeg et Udkast til et Brev fra Slutningen af Jan. 1916 til Kammerherre Har. Scavenius. Dette Brev var ledsaget af en Afskrift af et Andragende til den russiske Minister i Kbhvn. "Han tog vel imod det“" (staar der i mit Brevudkast), „og jeg har ganske godt Haab, men“ — sagde han — „det vil afhænge af Krigsministeriet i Petrograd“. Hint Andragende var om at faa en Præst til Pavlovo Possadskii. Der staar i mit Brev til Kmh. Scavenius: En velskikket Præest har jeg godt Haab om at finde“. Men at jeg kunde komme lidt op i Skyerne, bort fra den faste Jord, fremgaar af Fortsattelsen: „Om Russerne muligvis vilde tilstaa ham (Præsten) Frirejse paa Banerne, vilde det være en Lettelse, særlig hvis det maa blive betroet ham at rejse ud til Fangetransporternes Raststeder for der at foreslaa muligt tilstedeværende Sønderjyders Udskillelse“. Det hedder videre i Brevet: „Hvis den russiske Regering giver sit Minde til Præstens Udsendelse herfra, da vil jeg antage, at han paa Rejsen skulde købe adskillige Klædningsstykker og tage med til Fangerne". Og videre: „For 8 Dage siden rejste Dr. Anton Pedersen af den danske Ambulance til Petrograd. Han vilde fors $\phi \mathrm{ge}$, om han muligt kunde komme til den oprettede sønderjydske Særlejr, og han fik Penge med til at afhjælpe Nød for, bl. a. $470 \mathrm{kr}$. af 496 , som Frøken Scavenius, Søgaard, (Kammerherrens Søster), har indsamlet, gik den $\mathrm{Vej}^{\text {iss? }}$.

I et Brev af 9. Marts (25. Febr.) 1916 skriver Konsul Edstrøm om Præstespørgsmaalet: „At sende en Præst fra Danmark til S $\phi n-$ derjyderne i Pavlovo Possadskii mener jeg vil blive noget kostbart. Bedre vel da at sende dette Beløb til praktisk Hjælp, saa meget mere som det kan tænkes, at disse Sønderjyder kan blive afsendt til andet Sted. Konsulatet har idag af sendt Penge og B $\emptyset \mathrm{ger}$ til disse Sønderjyder".

D. 30. (17.) Marts 1916 skriver Kmh. Har. Scavenius: „Censureringen af Breve er et meget vanskeligt Spørgsmaal, idet Krigs- 
myndighederne ikke vil opgive deres Ret til at gennemse alle Breve. Ad direkte Vej er der saaledes ikke noget at opnaa. Jeg har imidlertid tænkt mig, at jeg vil foreslaa Konsulen i Moskwa at lade Krigsfangerne sende deres Breve til ham; han kan saa dernæst sende dem hertil, hvorfra de kan gaa med Kurér til Dem. Hvorvidt det kan lade sig gøre, véd jeg endnu ikke; man kan jo altid forsøge“. At Sønderjyderne havde en udmærket Ven i vor danske Minister i Rusland, fremgaar noksomt af dette Brev - ligesom af alle hans Handlinger ellers. Hvorledes det ellers gik med Censureringen, vides som $f \varnothing r$ nævnt ikke. Men det vides, at $i$ alt Fald Masser af danske Breve, baade til og fra Rusland, gik lykkeligt igennem. Breve, der var vigtige, gik igennem Legationen. Det vides ogsaa, at det senere ordnedes saaledes i Pavlovo Possadskii med den derværende saare elskværdige Kommandant, at - en af de sønderjydske Krigsfanger paa en Maade bes $\phi r g e d e$ al Censureringen!! Dette var jo unægtelig ogsaa det nemmeste og det simpleste! („De skriver om at være forsigtig. Ja, det er vi ogsaa nu. For uforsigtige Ytringer i Breve til Slesvig kan De nu være rolig. Kommandanten her censurerer nemlig alle Breve og Kort, inden de gaar ud af Lejren, og hans Tolk for den danske Korrespondances Vedkommende er jeg. Jeg giver alle Kort og Breve til Slesvig, der indeholder det allermindste om vor særskillelse, tilbage .... (En af Fangerne, 24. 7. 1916).

Om Præstesp $\varnothing$ rgsmaalet hedder det i nysnævnte Brev fra Kmh. Seavenius :

„I Øjeblikket vilde det næppe kunne svare Regning at sende en Præst herover.23 Mennesker er jo en lidt lille Menighed.Skulde det lykkes at faa alle eller en stor Del af S $\varnothing$ nderjyderne samlede i Pavlovo, skal jeg $\varnothing$ jeblikkelig tage Spфrgsmaalet op“.

Præstespørgsmaalet ordnede sig senere „af sig selv“ og paa allerbedste Maade. Der gik dog Aar og Dag, inden Pastor N. A. Jensen ved Majdagstide 1917 stod i Rusland og kom til der at virke mellem og for Landsmændene $\mathrm{i}$ om ved $1 \frac{1 / 2}{2}$ Aar. Jensen havde jo været 7-8 Maaneder i Frankrig, i Aurillaclejren, Vinteren 191516. Havde derefter hvilet sig ud herhjemme, men gjort dette paa den Maade, at han Danmark over havde holdt mangfoldige Møder om Sønderjyderne i Krigsfangenskab, da særlig dem i Frankrig. 
Og alt Overskuddet fra disse M $\varnothing$ der lod han gaa til en Kasse, der skulde sætte ham i Stand til at rejse til Rusland for at leve en længere Tid mellem og for de derværende sønderjydske Fanger. Sønderjyderne havde h $\phi$ rt om hans forestaaende Komme og længtes efter ham. D. 31. Marts skrev en af dem: „Vi havde haabet, at $\mathrm{Hr}$. Pastor Jensen vilde komme, men det synes ikke, at dette Haab skal opfyldes“. De første Dage i Maj naaede Pastor Jensen Petrograd, hvor der viste sig at være en hel Del Hindringer for ham at rydde til Side, saa at han først ind i Juni kunde rykke ind $i$ den s $\varnothing$ nderjydske Lejr, der nu forlængst var flyttet til Jurjeff Polskii.

Pastor Jensens Saga skal jeg ikke her komme saa meget ind paa, som den fortjener. Den er stor og rig, $h \varnothing j$ og ægte. Det var en Kærlighedshedrift, han udf $\varnothing$ rte, at drage ud til det vildsomme Rusland og blive der, blive der Tiden ud og næsten lidt til, blive der langt ind i Bolchevismens Tid. Delvis var det Lidelse, han tog sig paa. Han prøvede meget og døjede meget, Farer og Uhehageligheder, prøvede ogsaa at være D $\emptyset$ den nær i Ensomhed og Forladthed. Men hans Lod blev ikke at segne under Byrderne. Han havde den Lykke at komme levende hjem, efter først at have haft den vel endnu st $\varnothing$ rre Lykke at kunne skaffe Landsmændene hjem, vriste dem ud af Bolchevikkernes Tag og ruste dem til at slippe godt igennem de tyske Vagthold paa den Finske Bugt og i Riga. Derom véd i Virkeligheden I Sønderjyder jo lige saa god Besked som jeg. Og paa Punkter véd I mere end jeg véd. Men saa ved I ogsaa, hvor meget I har at vide ham Tak for. I vis Maade staar Pastor Jensen „alene“. Men aldrig vil han kunne blive en enlig Mand; thi sønderjydske Hjerter, baade fra „Frankrig“ og sidst og mest fra „Rusland“, vil lade ham føle Kærlighed. Han saaede Kærlighed, og det vil han ogsaa høste. Der var paa en Tid, da Jensen endnu var i Frankrig, sket Henvendelse til andre Præster om at drage til Rusland. Ja, de vilde jo nok, men vilde alligevel ikke; det blev til intet med dem. Saa kom Pastor Jensen hjem fra Frankrig og var fri Mand. Han vilde. Selv saa' han sig Rusland ud som Arbejdsmark, og Midlerne til at komme afsted for rejste han selv forinden ved sit Arbejde. — „Selv“ -, ja, men hvem gav ham Ilden og Kraften! At han var den gode og tro Tjner, det kan man da sige! Det sidste, Pastor Jensen foretog sig i Krigsfangesagen, var ejendommeligt for ham. 
De danske Sønderjyder, der som Krigsfanger var samlede i Rusland, kostede efterhaanden mange Penge. Alting blev saa dyrt, naar de ikke skulde sulte ihjel. De Danske i Rusland havde givet store Tilskud. Og Hjemrejsen med dertil hørende Udrustning var dyr. Direkt $\varnothing \mathrm{r}$ Erik Plum i Russisk Handelskompagni havde st $\emptyset t$ tet Sønderjyderne meget; ud over alt hvad han allerede forud havde gjort, laante han tilsidst Pastor Jensen adskillige Tusinde Kroner, for at Sønderjyderne dog skulde kunne slippe helt hjem og komme ordentlig hjem. Disse sidste Penge var at regne for et Laan, som det maatte vare andres Sag at indfri, selv om Hr. Plum tog Risikoen og var ikke uvillig til at bære ogsaa denne Udgift, om det skulde vise sig nødvendigt. Det var imidlerti!! Pastor Jensen imod, at Dir. Plum skulde staa længe i Forskud med disse Penge. Da Dir. l':m havde kvitieret 5000 Kr. som sit Bidrag, betalte Pastor Jensen derfor Restsummen selv, $7600 \mathrm{Kr}$., hvilket maaske var alt hvad han ejede og havde. Senere, forresten ikke straks, betalte Den S $\phi n-$ derjydske Fond disse Penge tilbage, som det da ogsaa maatte siges at vare Fondens Sag at klare. - Eet endnu dog: De rimeligvis mange Sønderjyder, der efter Jurjeffernes Hjemkomst endnu sad tilbage, spredt i Ruslands andre Fangelejre, fordi det ikke var lykkedes dem at naa frem til Jurjeff Polskii, laa Pastor Jensen inderligt paa Sinde. Og i Forening med Pastor Stchelkunoff lagde han Raad op og Planer om, at de to Mænd sammen skulde drage ud som Undsætningsekspedition og finde og frelse dem. Stchelkunoff var meget villig til at tage med. Men Forholdene var for vanskelige. Ønskerne kunde ikke virkeligg $\emptyset$ res. Tanken maatte opgives. Og derefter gled Pastor Jensen stille og beskedent ind i en stille og beskeden Stilling som Frimenighedspræst i Bovlund, hvor han indtil videre har stillet sig til Raadighed. Det sønderjydske Folks Tak vil følge ham, hvor han end slaar sig ned; hele det danske Folks Tak vel i Grunden ogsaa.

Pavlovo-Lejren blev jo flyttet til Jurjeff-Polskii, og det var i Jurjeff-Polskii, at Pastor Jensen fik sin Gerning. Det var ogsaa der, at han fik sin „Kirke“, det gamle Trykkeri, der blev sat i Stand til nyt Brug. Værd at nærne er det, at Pastor Jensen fra gammel Tid er stærkt knyttet til en sjællandsk Egn, Landet mellem Sjællands Odde og Vallekilde, Ods Herred kaldet. Odsherreds Præster 
paatog sig da ved Hjælp af deres Venner i Ods Herred at skaffe de Penge, der skulde til for at betale Lejen af „Kirken“ i Jurjeff; dette skete igennem Sognepræst $W$. W. Bagger i Asnæs, der ligesom dennes Præstevenner var inderligt glade for Pastor Jensens Virksomhed.

Naturligvis gik der en Del Penge fra Danmark til Krigsfangerne i Rusland, maaske ikke til saa stort et Beløb dog som de Underst $\not t$ telser, der faldt fra Danske i Rusland. Af hjælpende Landsmænd derovre er $\mathrm{i}$ det foregaaende næunt: Enkekejserinden, Minister Har. Scavenius, Direktør Erik Plum. Der er flere - Krigsfangerne véd vist selv bedre Rede derpaa end jeg -: med særlig Glæde kan jeg nævne: Direkt $\emptyset r$ P. F. Hansen (Dansk-Russisk Dampskibsselskab) og Fru Kontorchef E. Becksh $\phi t$. Denne sidste aabnede sit Hus i Petrograd i flere Maaneder for Fangerne, som dér fik Sysselsættelse og en udmærket Behandling. Paa et Tidspunkt i Januar 1918, da S $\varnothing$ nderjyderne var ved at komme dybt i N $\varnothing$, gjorde Fru Becksh $\phi \mathrm{ft}$ Udvej for et stort Bel $\phi b$, der fik den mest udmærkede Virkning.

Forbindelsen mellem Danmark og Sønderjyderne i Rusland blev ellers Krigen igennem narmest opretholdt gennem „Gudmødrene“, d. v. s. de Mennesker, der herhjemme paatog sig at sørge lidt for en Krigsfange i Henhold til de Vejledninger, der kunde gives for, hvad der kunde foretages af Omsorg. Krigsfangernes Adresser kom tilstede ad forskellige Veje. Med Bud fra Sønderjylland kom der adskillige; Grænseboer som Dr. N. Svith i Ribe, Dr. C. Gabe i Taps og Sognepræst H. I. F. C. Matthiesen i Vamdrup sørgede for en Del. Sønderjydske Aviser kunde nu og da se deres Snit til at bringe Adresse paa en Sønderjyde i Fangenskab. Og, som foran fortalt, kunde der fra Rusland, fra den danske Legation, blive sendt Navne med Adresser. Adresserne skulde saa fordeles til "Gudmødrene“. Dette m. m. m. ordnedes af Fru Clara Thomsen og Frk. G. Nygård, Dag for Dag, Maaned for Maaned og Aar for Aar. „Gudmødrene“ kom tilveje ved at forskellige Mennesker spurgte deres Bekendte: „Vil De ikke have en s $\varnothing$ nderjydsk Krigsfange?“„Hvad vil det sige?“ - „Jo, saadan og saadan ....“. Ved s $\varnothing$ nderjydske og andre nationale M $\phi$ der kunde det ofte hænde, at der blev læst Breve eller Brudstykker af Breve op, der var komne fra 
Disse var sendt pd skovarbejde $t$ Ruslands indre. Nik. Jensen - Sk $\phi t$ Peter C. Petersen - Hans Hansen

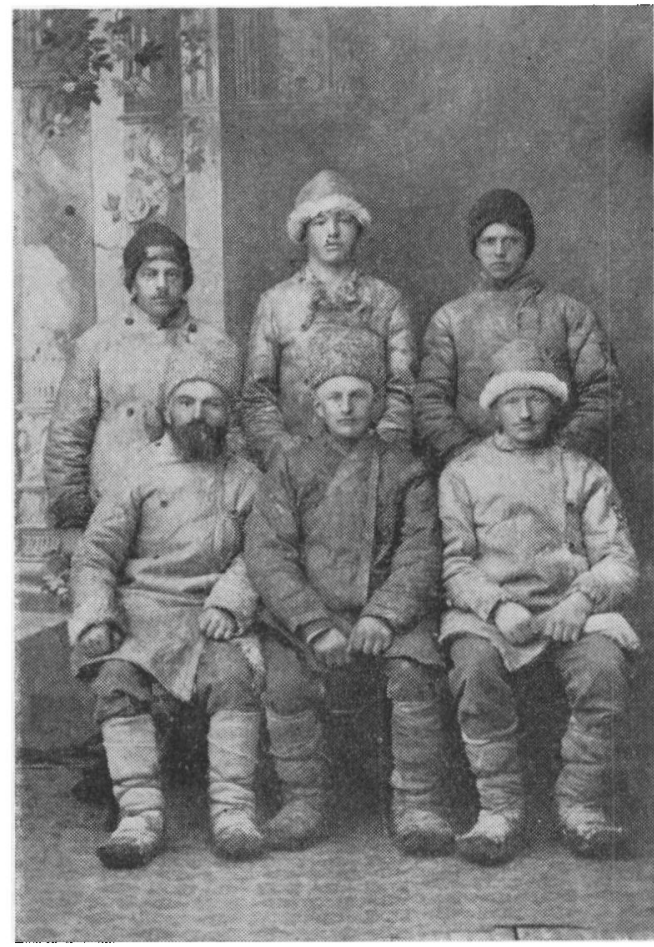

Sønderjyder ude i Krigsfangenskab; og der kunde saa blive gjort opmærksom paa, at hvis nogen vilde have sig en „Guds $\varnothing$ n“, saa var det bare at melde sig. Ogsaa gik det tit saaledes, at en „Gudmoder" skrev eller telefonerede, at denne eller hin af hendes (hans) Omgangskreds $\varnothing$ nskede ligeledes at faa en „Guds $\emptyset$ n“. Studenterne $A d$. Flensmark og $M$. Neiiendam var virksomme for at skaffe „Gudm $\phi$ dre“, Frk. M. Bennike ligeledes. (Kun i Aviserne kunde Sagen ikke nævnes; thi saa vilde nok den tyske Gesandt være vandret hen til de daværende danske Ministre og have frabedt sig, at man fra dansk Side gjorde godt imod tyske Statsborgere -rort eget K $\phi \mathrm{d}$ og Blod $\mathbf{d o g}$ !) Nej, alt dette maatte gaa i Hemmelighed, som "fortroligt“. - Direkt $\varnothing \mathrm{r}$ Asger Bruhn, Bestyrelsesmedlem i „S $\varnothing$ nderjydsk Central-Forening“, skaffede fra sin Forening mange „Gudm $\varnothing d r e “$. Den nævnte Forening var for $\varnothing$ vrigt fra f $\phi r s t$ 
til sidst et godt Rygstød for Arbejdet herhjemme ved at betale Trykningsudgifter og Porto $\mathrm{m}$. m., hvilket Foreningen selv bød sig til med. Paa Tale om "Trykningsudgifter" b $\phi r$ det siges, at i Bogtrykkerne Schou \& Madsen havde Krigsfangerne to gode Venner med billigt Arbejde for Fangerne. Der var andre s $\varnothing$ nderjydske Foreninger end „S. J. C. F.“, der hjalp: Ogsaa Foreningerne „To L $\phi-$ ver“, „S $\varnothing$ nderjydsk Samfund“, „De samvirkende“, „S $\phi$ nderjydsk Forening for København og Omegn“, „4 S.“ og Foreningen „Danebrog“ traadte st $\varnothing$ ttende til, naar der kaldtes paa dem. En anden Forening var der, som hjalp og hjalp meget: Det var „Danske Kvinders Forsvarsforening ". Denne virkede især med at sætte sine Medlemmer Landet over i Gang med at sende Gavepakker i store Strømme til Juleaften, naar denne stod for D $\phi$ ren. Det var Fru Overretssagf $\phi \mathrm{rer}$ Julie Friderichsen, der var det varme, bankende Hjerte i denne „D. K. F.“-Bevægelse fra det $\emptyset$ jeblik hun stillede sig i Spidsen for Julepakkesagen og saa længe, der var noget at gøre. Andre varmhjertede danske Kvinder har lagt sig i Selen for Fangerne. Her kan nævnes nogle: Fru Professorinde D. Schmicgelow, Frk. Anna Thalbitzer, Frk. Ea Dinesen (senere gift Neergaard), Frk. Marie Fergo (kendt, eller i alt Fald hendes Virksomhed kendt og skattet af mangen en tobakselskende Krigsfange, ligesom ogsaa paa anden Maade) ...." (Endnu en Række Navne nævnes).

„Mange Gaver blev sendt til Rusland. Ikke lige saa mange desværre blev modtagne af dem, der skulde have haft dem. En Del af det sendte kom dog til Vejs Ende og blev til den Hjælp, der var Meningen dermed. At vore kære sønderjydske Venner var glade derfor, gjorde os lykkelige.

Og saa fik Fangenskabet omsider Ende, endda f $\varnothing \mathbf{r}$ Krigen var helt forbi. Tilmed blev $I$ de f $\varnothing$ rste, der kom hjem. Vi husker endnu, nogle af os, hvorledes I Uge efter Uge over Sverige kom hjem hertil, i Smaaflokke paa 3-6 og i dybeste Stilhed. Ikke blev I modtaget med Taler og Fester. Jo, Festen bragte I selv, den fyldte Jert lykkelige Sind. Tarvelig Mad blev Jer budt, men den smagte Jer kongeligt som den danske Mad, den var. Tarveligt Natteleje blev Jer redt, S $\varnothing$ stersenge paa en Gymnastiksals Gulv, ogsaa det syn- 
tes I om: I havde jo ikke set Seng i Aaringer. Og saa var I i Danmark! det var jo dog det bedste for Jer af alt, det bet $\phi d$, at I var hjemme. Og de Allieredes fulde, hele Sejr var nær; det bet $\varnothing \mathrm{d}$, at. ogsaa Sønderjylland skulde komme hjem.

Et Brev fra en af Jer, Jer Skriftfører, skal jeg maaske kalde ham, ligger for mig. Han skrev saa tidlig som i Juli 1916: „Vi trøster os jo med, at der ikke bliver ret meget tilbage af Tyskland, for skal vi derigennem, vil vi vist ikke alle kunne undgaa Ubehageligheder .... Det vil derfor være os en stor Glæde, om vi elter Krigen kunde stige i Land paa Toldboden som danske Undersaatter. Ja, hvor vilde denne Gensynsdag da blive til en Helligdag for os, der ikke taler om meget andet her end om alle de Fremtidshaab, Freden vil opfylde“.

Helligdagen kom, godt 2 Aar derefter.

Helligdag forestaar nu igen, da det halve Sønderjylland snart lægges i sin Moders Favn. Give Gud, at denne Genforening maa stemme vort Sind til hellig Andagt og Tak! Give Gud, at Sønderjyllands og det фvrige Danmarks Fællesliv maa blive saa lyst og lykkeligt, som nu engang Forholdene her paa Jord vil tillade. Og endelig: Give Gud, at ogsaa den store Helligdag maa oprinde, da alt dansk samles, hele Danmarks Rige; da alle de, der endnu maa staa ude, ogsaa lukkes ind, lukkes ind i Faderhuset!

Og alle I, der kom hjem fra Krigens vilde Larm og fra Fangenskabets triste Tid, Jer hilser vi paany hjerteligt

\section{Velkommen hjem til Frdrelandet!}
Den 5te Juni 1920.
N. H. Rasmussen ${ }^{\text {«as }}$.

Det ejendommelige ved denne beretning er, at N. H. Rasmussens eget navn ikke nævnes. Der står så godt som intet om, at han selv var med i arbejdet, - til trods for, at det var ham, der stod i spidsen for det og var den drivende kraft $i$ det. At han var dette, véd enhver af de pågaldende krigsfanger; men $\mathrm{i}$ beretningen her må man læse det mellem linierne, hvor det til gengæld står meget tydeligt.

I formaliteten holder den sig til den givne opgave: at svare på, „hvem der havde arbejdet . ...“, og gør det ved omhyggeligt at opregne en mængde medvirkende kræfter. Denne opregning er kor- 
rekt; enhver af disse næunte havde gjort en indsats, nogle af dem en betydelig indsats; der var også flere end de nævnte, cler havde været med; hjælp og medvirken kom spontant fra alle landets kanter, - det var lidt af en folkebevægelse.

I realiteten viser beretningen imidlertid, at hovedårsagen til, at sagen kom til at skride, var N. H. Rasmussens utrættelige virksomhed.

Vi ser f. eks., at den russiske legationspræst i København, I. Stchelkunoff, omtales på side 56, og det angives, at han var ,en god rådgiver". Ja, men for hvem da? For N. H. Rasmussen selvf $\varnothing$ lgelig, - jfr. brev 19/9 1926 fra pastor S. til mig:

"... Det var mig, der arrangerede det første M $\varnothing$ de mellem Deres Fader og Buxhoeveden, og jeg var siden ofte til Stede ved hans Møder med Gesandten; da Deres Fader f $\phi$ lte sig besværet af at skulle tale et fremmed Sprog med Buxh., gik det paa Dansk med mig som Tolk; det var egentlig sjældent, at han skrev til mig, i Reglen telefonerede han til mig, og vi satte saa hinanden Stævne i Gesandtskabet; han havde jo altid saa meget at bede om for sine .elskede S $\phi$ nderjyder .... “.

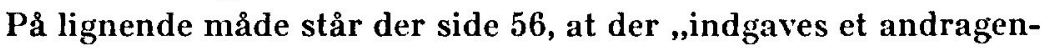
de til Ruslands minister ...”; men der står intet om, at det var $\mathbf{N}$. H. Rasmussen, der indgav det; for at få dette at vide, må vi til arkivet og se kopien af skrivelsen. Svarskrivelserne (side 58-60) er også gengivet med udeladelse af $\mathbf{N}$. H. Rasmussens navn. Heller ikke med hensyn til konsul Nissens medvirken er der givet udtømmende besked (side 60). Vil vi have en sådan, må vi søge til en beretning, som N. H. R. i 1923 sendte til kontorchef Boeck i det danske udenrigsministerium. I denne hedder det:

„.... Senere afd $\phi$ de Konsul i Rostov i Syd-Rusland, Andr. Nissen, var i Foraaret 1915 paa Bes $\varnothing \mathrm{g}$ her i København. Jeg s $\varnothing$ gte ham og talte med ham om dette Sp $\varnothing$ rgsmaal og $\emptyset$ nskede, at han, der selv var S $\varnothing$ nderjyde, skulde, naar han kom tilbage til Rusland, s $\phi$ ge Audiens hos H. M. Enkekejserinde Dagmar og prøve paa at faa hendes mægtige Støtte til denne Sags Ordning. Konsul Nissen sagde, at dette kunde han godt. Han var, sagde han, tit bleven modtaget af Kejserinden, hvem det flere Gange havde behaget at tage imod Blomster af hans Haand. „Men“ — f $\not$ jede han beklagende til 
- ,jeg slipper bare ikke ind, her i disse Krigens Tider. Ja, kan De skaffe mig en Introduktion!" Introduktionen blev skaffet. Men her var det atter Pastor Stchelkunoff, som jeg maatte henvende mig til ....."

Der foreligger et brev af 11. marts 1915 fra konsul Nissen til N. H. Rasmussen. Det hedder deri :

„Jeg undlader ikke at meddele Dem, at jeg ved mit Besøg hos den russiske Legationsprast Tschelkunow omtalte Deres Sag, og bad ham om at forskaffe mig noget, hvorved jeg kunde opnaa en Audiens hos Hs. Majestæt Enke Kejserinden ....

.... De veed, Hr. Rasmussen, at jeg staar til Deres Disposition, og at jeg ved mit Bekjendtskab med Enke Kejserinden, kan tale frimodigt med hende, og opnaa meget - men for at komme til hende - nu som Privatmand og uden Hjælp af Gesandtskabet, b $\emptyset \mathbf{r}$ jeg have dette Introduktionsbrev fra Præsten eller den herværende russiske Gesandt.

Vilde De nu være saa god at trykke efter, ved et Bes $\emptyset \mathrm{g}$ hos Præsten eller Gesandten, saa gaar Sagen i Orden . . . . “"

N. H. Rasmussen skriver i et brev den 31/5 1922 til pastor N. A. Jensen: „.... Med megen Besvær fik jeg en Mand (Konsul Nissen fra Rostow) sendt op til Kejserinden, efter at jeg havde talt med ham her i Byen .... "* .

Enkekejserinde Dagmar tog imod sagen med den største velvilje, ,begærede af det danske Gesandtskab i Petrograd, at det skulde skaffe hende Adresserne paa alle de s. j. Krigsfanger i Rusland og lagde $i$ det hele den mest levende Interesse for Dagen " Hendes majestæet skaffede sig listerne over krigsfangerne og gav dem videre til den danske minister i Petrograd, kammerherre Harald Scavenius og bad ham afmærke navne, der var sønderjyder. Han sendte N. H. Rasmussen listerne, og efter at denne havde udpeget de sфnderjyske navne, blev listerne sendt til kejserinden, som derefter gav de russiske militære myndigheder ordre til at samle sønderjyderne i en særlig lejr ${ }^{28}$.

Noget af værdien ved samlingen af sønderjyske krigsfanger (desværre alt for få af dem!) i deres egen særskilte lejr var den, at pastor $N$. A. Jensen opholdt sig hos dem i halvandet år i JurjeffPolskii og holdt danske gudstjenester for dem, foredrag og sam- 
taler. Det kan ikke noksom anbefales at læse hans egen skildring heraf $i$ hans bog VENTETIDER, 1926.

Om, hvordan dette kom i stand, kan vi bl. a. læse $i$ et brev ${ }^{-}$af 11/1 1916 fra N. H. Rasmussen til pastor N. A. Jensen, som på dette tidspunkt opholdt sig i den sønderjyske fangelejr i Aurillac i Frankrig:

„Men nu en helt anden Ting. Oberst Meyer, „Skyttemeyer“, var sendt ud for at se paa Fangelejre i Rusland, og havde jo lidt Bud med derover til højere Vedkomende om Sagen, hvilken der forresten har været rørt ved adskillige Gange. D. 1. Dec. skrev Meyer til mig: „Den Samling, som De фnsker, vil blive foretaget“ (La concentration, que vous souhaite, séra etablé“). Meddelelsen var 5 Uger om at komme herhjem; saa langsomt gaar det til den Side. Saa talte jeg med den russiske Legationspræst her og spurgte ham, om han troede, at vi kunde faa Lov at sende en Præst derover. Dette mente han var en given Sag. Idag ringede han op; han havde talt med Ministeren; det var ganske rigtigt, de var samlede paa ét Sted, hvor vidste han dog ikke. Min. mente, at der sagtens blev Adgang til at faa en Præst derned; jeg skulde skrive til Legationen derom, saa vilde der komme Svar senere, og ganske sikkert tilfredsstillende Svar. Dernæst spurgte jeg Holger Petersen om Pengevæsenet. „Ja, se nu f $\varnothing$ rst at finde Præsten, saa kommer Pengene nok (Han havde dem dog ikke) “.

Altsaa: Præsten! Dette bliver ikke lige saa nemt som med Dem*. For De gik jo der og var f $\not d t$ og baaret til det og var løs og ledig. $\mathrm{Nu}$ spфrger jeg mig for hos forskellige, om de har nogen, de kan tænke sig. Ogsaa Dem vil jeg gerne spørge, om De skulde tænke Dem nogen. Nogen som paa Forhaand har Forstaaelsen af Sønderjylland og S $\varnothing$ nderjyderne; som har Hjærtet dertil, og som, her kommer der en Vanskelighed, ikke har for stor en Familie, helst ingen. Det vil jo ikke være nemt for Præstekone og Præsteb $\phi$ rn at drage helt bort til Østasien, eller hvor det bliver. Skulde det lykkes Dem lykkeligt at komme i Tanker om nogen .... “"

Det lykkedes ikke at finde nogen anden til dette hverv; det blev

* d. v. s. som med at få pastor Jensen til at rejse til Frankrig. B. R. 
N. A. Jensen, som efter sit korte ophold i Frankrig også gik ind på at tage til Rusland ${ }^{40}$.

At få denne sag bragt $i$ orden mødte imidlertid st $\emptyset$ rre vanskeligheder end som så. Den gik i virkeligheden først i orden, da så højststående personer trådte til, at det ikke vil være passende her at komme ind derpa't" I november $1916 \mathrm{kom}$ endelig tilladelsen, $\mathrm{i}$ form af en skrivelse fra det russiske Røde Kors til det danske Røde Kors, hvori det bl. a. hedder, at „de vedkommende autoriteter meget gerne tillader hr. pastor Jensens bes $\emptyset g$ (à la visitation) hos de danske krigsfanger"“".

Lige så glædeligt dette var, lige så kedeligt var det, at det ikke fremgik klart, om ,visitation“ bet $\emptyset d$, at $N$. A. Jensen måtte opholde sig i lejren til stadighed. N. H. Rasmussen turde ikke lade ham rejse på dette papir, og man tilbragte vinteren med at sфge en bedre tilladelse. I marts kom sả revolutionen, og nu var der nye mænd på alle kontorer, således at der for pastor Jensen intet andet var at gøre end at rejse derover og forsøge med personlig henvendelse på kontorerne. Endelig den 14. juni 1917 nåede han Jurjeff-Polskij ${ }^{33}$. Om hans virksomhed her skal ikke på dette sted fortalles nærmere; men det kan roligt fastslås, at den bidrog til at gøre fangernes tilværelse mere menneskeværdig.

Med ovenstående skulle det være oplyst, hvilken rolle N. H. Rasmussen har spillet som initiativtager og drivende kraft $i$ denne sag, navnlig hvad angår bestræbelserne for at få oprettet særlig lejr for sønderjyderne i Rusland.

Men samtidig forblev han i stor udstrækning bag kulisserne med sin egen person. Hovedsagen for ham var at få andre sat $i$ arbejde. Selv havde han fuldt op at gøre, hvad i nogen måde beroede på, at han ikke betjente sig af moderne kontororganisation, men sad og skrev i hundredvis af håndskrevne breve til enkelte krigsfanger og netop herved fik givet udtryk for det, som var det værdiskabende $i$ hans arbejde: hjertelaget. Men fremme i offentlighedens lys sås han ikke. Dette hang nu også sammen med, at under krigen 1914-18 førte den siddende danske regering Zahle en udenrigspolitik, som medf $\phi r t e$, at man s $\emptyset$ gte at undgå, at nogen dansk borger foretog nogetsomhelst, som kunne virke udæskende på $T_{j}$ sk- 
land. Hele arbejdet herhjemme for de danske sønderjyder i krigsfangenskab havde derfor en nogenlunde "underjordisk“ karakter.

Det må derfor ikke undre, når det har været vanskeligt for eftertiden at danne sig et klart billede af, hvad der foregik. Redeg $\phi-$ relsen i den store „Sфnderjyllands Historie“ er således ikke uangribeligt. Nærværende afhandling har til hensigt at virke $i$ alt fald i nogen måde oplysende.

Det er med ejendommelige f $\varnothing$ lelser, man har siddet og skrevet disse linier i 40-året for krigsfangernes hjemkomst til Danmark fra England og Frankrig. Siden den tid har der været endnu en krig, som ingen af os i 1920 troede på muligheden af. Mange af krigsfangerne er nu døde, mange af deres venner ligeledes, $\mathbf{N}$. $\mathbf{H}$. Rasmussen allerede i 1924; men endnu er der en del mennesker, som kan huske nogle af disse stærke begivenheder - store og små — under „Verdenskrigen“. - - De gamle dogmatiklærde i den lutherske kirke lærte, at „Gud har et firedobbelt forhold til det Onde: han tillader det Onde; han begrænser det Onde; han hindrer det Onde, - og han leder og vender det Onde“. Dette snurrige fors $\phi g$ på at sætte ul $\varnothing$ selige gåder på en formel rummer alligevel dybe sandheder. Det er underligt — og trøsterigt - at tænke på, at krigen, som medf $\varnothing$ rte usigelig n $\varnothing d$ og sorg, også fik givet anledning til små lyspunkter, nemlig der hvor forholdene udløste hjertelag og hjertevarme og gav frit løb herfor. 


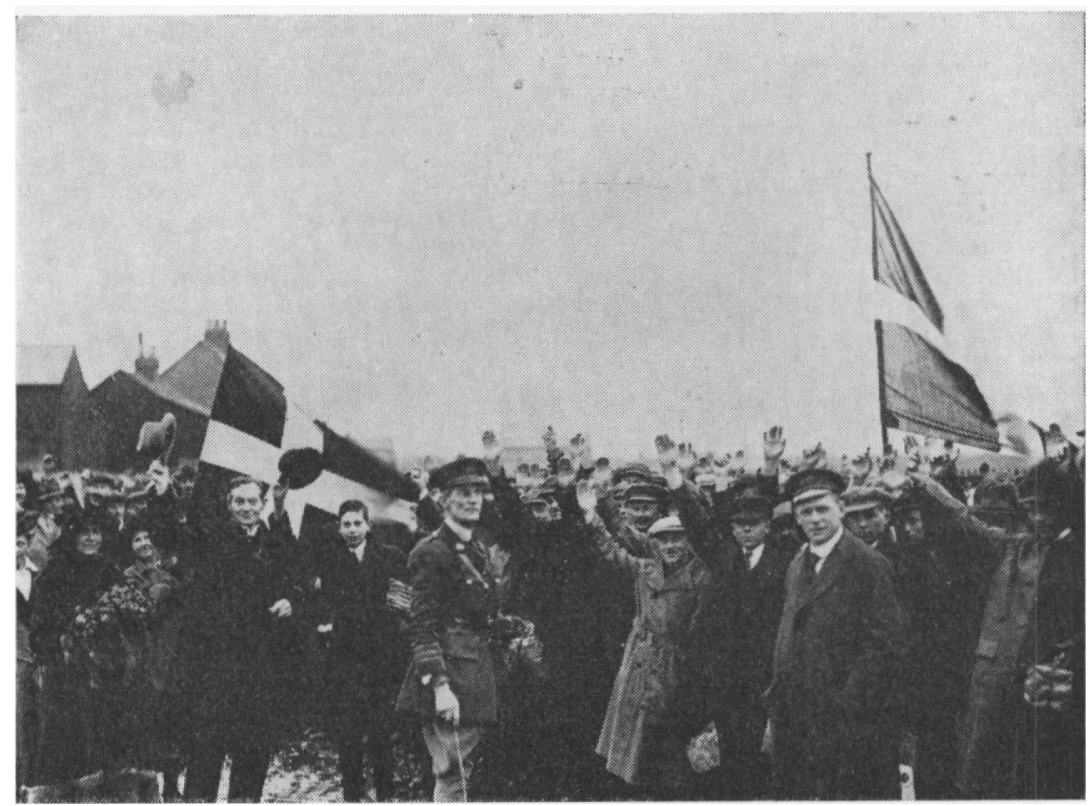

NU ER DAGEN DER, VI VIL HJEM!

Afrejse fra Feltham. Forrest fra venstre: fru Troensegaard-Hansen, pastor Troensegaard-Hansen, Erling Troensegaard-Hansen, lejrchefen oberst Johnson.

Under bortmarchen sang mandene:

Der er langt hjem thl Sønderjylland, der er lang vej at gâ gennem fremmede herrers lande, over bølgerne de blá.

Men tankerne flyver, for dem er der kort til vor hjemstavn hist i Sønderjylland, det land, som er vort.
Der er langt hjem til Sфnderjylland, dér hvor minderne bo, hvor vor fribårne slæąt har hjemme med vort háb og med vor tro. Mens larkerne kvidrer derhjemme på vang, sã vil her vi $i$ det fjerne synge vort hjemland en sang.

Der er langt hjem til S $\phi$ nderjylland, men vi kommer engang, vi har for lart den kunst at vente, korte tiden med en sang.

Vi kommer, ja, vi kommer, sâ snart som vi kan, fa, og măske kommer vi med sommer ior vort folk, vort land.

(Skrevet til Feltham-fangerne af Ahrent otterstrom, Tonder, pa melodten $\gg$ Tipperary $\propto$, de engelske soldaters yndlingssang). 


\section{NOTER}

Min væsentligste kilde er: Gymnastikdirektør N. H. Rasmussens privatarkiv vedrørende krigsfangearbejdet, 22 pakker (ca. 9000 breve og bilag) på Rigsarkivet. Kartoteket findes i de to sidste pakker.

Desuden har jeg benyttet: Bent Rasmussen: I Gerning og Sandhed ( $N$. H. Rasmussen og de sonderjydske krigsfanger), Kbh. 1927; N. A. Jensen : Ventetider (Breve fra rejser til de sønderjydske fangelejre i Frankrig og Rusland), Kbh. 1926; Aurillac Tidende, Haderslev 1920 og Slagelse 1921; Feltham Mindebogen, Kbh. 1921; N. A. Jensen og Andr. TroensegaardHansen: Rejsebreve fra krigsfangelejrene, 1916-1919, 1 expl. på Det Kongelige Bibliotek, 1 expl. i N. H. Rasmussens privatarkiv, pk. II, 1 expl. på Flensborghus Bogsamling; N. H. Rasmussens breve til Troensegaard-Hansen (anvendt i min bog ,I Gerning og Sandhed“, derefter er disse breve gået tabt, imidlertid er det i „I G. og S.“ anførte benyttet $i$ nærværende).

I citater er så vidt muligt forfatternes egen retskrivning fulgt.

De forskellige anforte mundtlige opgivelser til mig i 1926 er nedskrevet umiddelbart efter de pågældende samtaler; protokollen over disse findes i N. H. Rasmussens privatarkiv, pk. I, hvor også de skriftlige udtalelser til mig om sagen findes.

Forkortelser: Hvor intet andet er anfort, findes kildematerialet i $\mathbf{N}$. H. Rasmussens privatarkiv; det anforte tal angiver da den pågældende akts løbenummer i dette arkiv. Står der "Or.“ foran tallet, foreligger det pågældende brev i original, „Af." foran tallet betyder, at det foreligger i afskrift, „Kl.“ betyder kladde.

NHR $=\mathbf{N}$. H. Rasmussen $; \mathrm{PV}=$ Paul Verrier; NAJ $=$ N. A. Jensen; Tr. $\mathrm{H}=$ Troensegaard-Hansen.

E. I, E. II o. s. fr.: Pastor Troensegaard-Hansens rejsebreve fra England. - R. I, R. II o. s. fr.: Pastor N. A. Jensens rejsebreve fra Rusland.

1 Se endvidere: Paul Verrier: „Frankrig og Sønderjylland“ s. $235 \mathrm{ff}$. i Dahl \& Linvald: "Sonderjylland“, bd. II ; Verrier i "Aurillac Tidende" 1920, s. 5; en samtidig beretning fra Verrier (Af. 487); brev 24/1 1915 fra PV til Hans Mardsen (Af. 6086). Når man fra anden side (Berlingske Tidende $23 / 8$ 1914) har villet hævde at have opnået noget $i$ denne sag, savner det ethvert fornuftigt grundlag. Aurillac Tidende 1920.

2 ..Paul Verrier og Norden“, s. 101; brev 11/12 1914 fra NHR til PV.

3 Brev 8/1 1915 fra NHR til Tr. H.

4 NHR i brev 29/12 1915 til Tr. H.

5 NHRs redegorelse: indledn. til samlingen af NAJs rejsebreve, Flensborghus Bogsamling (Af, 4898).

6 Tr. H.: Breve om fangelejrarbejdet f. sønderj. i Engl. under verdenskrigen 1914-18. Desuden: „Feltham Mindebogen“.

7 NHR i brev 7/10 1916 til NÄJ; Tr. H i brev 13/7 1921 til HNR (Or. 9470); NHR i efterskrift til E VI.

8 Tr. H maj 1917 i E. VIII.

9 NHRs engelske kladde: 404 a-h.

10 NHR i brev til fru Thomsen $4 / 81915$ (9614).

11 Samtale mell. Tr. H og mig 21/10 1926.

$12 \mathrm{Tr} . \mathrm{H}$ i samtale med mig $23 / 71926$.

$13 \mathrm{Tr}$. H i samtale med mig 21/10 1926 (efter en omtale af mødet d. 8/6 1915): Tr. $H$ havde tidligerc ved forskell. lejligheder talt med War Office om at udskille sonderjyderne i en sarlig lejr. 
14 Oberst Larking i brev til mig af $6 / 11927: \ldots . .$. as far as I can recollect, it was early in 1915 that the project of a definite camp for the prisoners interned in this country, who were not in sympathy with Germany, was first considered".

15 „M. h. t. fangerne i Engl., da har der jo fundet mangehånde henvendelser sted derovre dels herfra og dels derfra. Men hovedslaget er slået af prof. P. V., der på sin regerings vegne drog op til London og fik det udvirket hos den eng. Reg.“. (NHR i brev til fru Thomsen 4/8 1915. 9614).

16 Af. 9553.

17 Af. 9558.

18 Brev 10/6 1915 fra Tr. H til NHR (605).

19 Brev til mig fra Tr. H 23-30/11 1926.

20 Brev $10 / 61915$ fra Tr. H til NHR (605) : brev 18/11 1926 fra PV til mig; en samtidig håndskreven beretning fra PV (til NHR. 486). Nærværendł gengivelse af samtalen hviler på et mundtligt referat, givet mig af Tr. $\mathrm{H}$ d. $23 / 71926$, samt på brev $23-30 / 111926$ fra Tr. H til mig.

21 „Krigsministeriet, London S. W. 21. juli 1915.

\section{MEMORANDUM}

Krigsministeriet har behandlet spørgsmålet om at oprette en særlig interneringslejr for sådanne krigsfanger, som tilhører nationer, som er de allierede mere eller mindre venligtsindede, og jeg skal herved overdrage Dem en liste over de forskellige nationaliteter, hvorf ra der er interneret fanger her $i$ landet.

Man regner med at anmode Dem om at være så elskvardig at undersøge slesvigernes forhold og med dette formål at bes $\emptyset$ ge de lejre, hvori disse er anbragt, for at fastslå berettigelsen af deres $\phi$ nsker orm at blive anbragt hos den pågaldende nationalitet. Det vil i den anledning blive nodvendigt, at De udarbejder en fuldstændig liste over dem, hvis onske De - ud fra Deres praktiske erfaring - anser for berettiget. Det bor bemaerkes i ethvert enkelt tilfæelde, hvorvidt den pågældende har udtalt onske om at flytte til en lejr, hvor han vil komme til at være sammen med de ovrige næunte nationer; der vil ikke blive gjort nogen forskel med hensyn til den almindelige behandling.

Der vil, for at sætte Dem i stand til at gennemfore dette hverv, blive sarget for et pas til Dem, som giver Dem adgang til de forskellige interneringssteder, og desuden et jernbanekort, som giver Dem ret til fri rejse på den pågældende rute. En kopi af dette kort er vedlagt nærværende skrivelse. Den undersøgelse, som De skal foretage, er naturligvis kun af foreløbig karakter, og det er meget vigtigt, at den ikke forer til stridigheder mellem fangerne på grund af misundelse eller ærgrelse fra deres side, som ikke udvælges". (Oversættelse fra Af. 4773 ; or. er i Tr. Hs privatarkiv, Det Kongelige Bibliotek).

22 Brev 27/7 1915 fra Tr. H til NHR (580).

$23 \mathrm{Tr}$. Hs mundtlige oplysning til mig d. 20/10 1925.

$2430 / 11$ 1917: 265 fanger.

25 7548. Retskrivningen er bearbejdet.

26133.

27134.

28 Kopi af selve skrivelsen til de Buxhoeveden: 4854 . 
29 Or. 395.

30 Or. 385 .

31 Or. 389

32 Kladden: 387.

33 Kl. 456.

$34 \mathrm{Kl} .460$.

35 Or. 394.

36 105. Desuden: „Afd. Konsul Nissen, Deres Fader og jeg har i alt Fald en Gang slaaet en Sludder af sammen i Gesandtskabets Forstue ...." (pastor Stchelkunoff i brev til mig d. 19/9 1926).

37 NHR 9/4 1915.

38 H. Scavenius i samtale med mig d. 23/8 1926; professorinde Schmiegelow i samtale med mig d. 6/10 1926.

3916.

40 Brev 4-5/2 1916 til NHR fra Aurillac: „.... Rusland. Ja hvis der virkelig er en samlet flok, arbejdsfri, så send mig! hvis ingen anden findes .....".

41 Samtale mellem professorinde Schmiegelow og mig d. 6/10 1926.

42 Facsimile: „Ventetider“, s. 121.

43 Samtale mellem NAJ og mig d. 27/7 1926.

44 la Cour, Hjelholt og Iund: „Sønderjyllands Historie“, Kbh. 19301943 , bd. 5, fra s. 264, 1.19 til s. 265, 1. 14. Fremstillingen er skrevet af Hans Lund.

Af denne redegørelse får læseren let indtrykket af, at $i$ arbejdet for krigsfangerne var oprettelsen af særlejrene det altoverskyggende væsentlige, medens korrespondancen fra Danmark var af ret underordnet betydning. Således må sagen imidlertid ikke så gerne opfattes. Krigsfangerne værdsatte denne korrespondance meget højt.

En vigtigere anke er, at NHRs navn kun nævnes i forbindelse med denne korrespondance og ikke $i$ omtalen af lejrene. Hans andel $i$ arbejdet for oprettelsen af lejrene i England og Rusland skulle være godtgjort ved nærværende artikel, ligesom også ordningen i Frankrig på flere punkter skyldtes et samarbejde mellem PV og NHR. Hans Lunds fremstilling kan ikke godt undgå at bibringe læseren den opfattelse, at $i$ alle tre allierede lande skal årsagen til sonderjydelejrenes oprettelse søges i professor Verriers initiativ. Denne opfattelses rigtighed må jeg bestride; forholdet er mere kompliceret; N.H. Rasmussen bor nævnes som den, der (sammen med de to præster) i væsentlig grad bar arbejdet for sønderjyderne i England og Rusland. 